\title{
Mahalle Mescitlerinin Akustik Konfor Analizi: Konya'dan İki Örnek
}

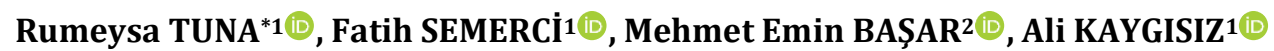 \\ ${ }^{1}$ Necmettin Erbakan Üniversitesi, Güzel Sanatlar ve Mimarlık Fakültesi, Mimarlık Bölümü, 42090, Konya, Türkiye \\ ${ }^{2}$ Konya Teknik Üniversitesi, Mimarlık ve Tasarım Fakültesi, Mimarlık Bölümü, 42250, Konya, Türkiye
}

(Alınış / Received: 01.03.2021, Kabul / Accepted: 21.05.2021, Online Yayınlanma / Published Online: 25.12.2021)

Anahtar Kelimeler Akustik konfor, Hacim akustiği, Simülasyon,

Kültürel miras,

Mahalle mescidi
Özet: Kültürel mirasın akustik açıdan belgelenmesi ve konfor analizi son yıllarda önemli bir çalışma konusu haline gelmiştir. Bu konu hakkında yapılan çalışmalar mimari koruma alanına yenilik kazandırmıștır. Kültürel miras olarak tanımlanan Anadolu Selçuklu dönemi mahalle mescitlerinin akustik performanslarının değerlendirilmesi ve özgün akustik konfor koșullarının ortaya konularak, yapılacak restorasyon çalışmalarına işık tutması, söz konusu mirasın gelecek kuşaklara aktarılması açısından önem taşımaktadır. Çalışma kapsamında hem konuşma hem de dini musiki işlevini taşıyan Konya mahalle mescitlerinin arasından örnek alan olarak seçilen Hoca Hasan Mescidi ve Taş Mescit' in akustik özelliklerinin belgelenmesi ve akustik konfor şartlarının değerlendirilmesi amaçlanmıştır. Mescitlerin akustik konfor analizi matematiksel veriler üzerinden akustik simülasyon yöntemi ile değerlendirilmiştir. Bu bağlamda mescitlerin üç boyutlu modellemeleri yapılarak, ODEON Akustik Simülasyon Programına aktarılmıştır. Kaynak ve alıcı noktaları, yüzey malzemeleri, optimum değer kabulleri yapılarak akustik simülasyon yapılmıştır. Belirlenen eylemler ve hacim akustiği parametreleri ıșığında ayrı ayrı simülasyon sonuçları incelenmiş, sonrasında analiz sonuçları birbirleriyle karşılaştırılmıştır. Sonuçta mahalle mescitlerinin akustik konfor koşulları ile ilgili çıkarımlar yapılmış ve önerilere yer verilmiştir.

\section{Acoustic Comfort Analysis of Neighborhood Masjids: Two Cases from Konya}

\section{Keywords}

Acoustic comfort,

Room acoustics,

Simulation,

Cultural heritage,

Neighborhood masjid

\begin{abstract}
Acoustic documenting of cultural heritage and comfort analysis have become an important subject of study in recent years. Studies on this subject have brought innovation to the field of architectural conservation. Having defined as a cultural heritage, neighborhood masjids of the Anatolian Seljuk period are of importance to transmit aforementioned heritage to future generations to reveal the acoustic performances and to shed light on how the restoration works ougth to be carried out. Within the scope of the study, it is aimed to document the acoustic characteristics and evaluate acoustic comfort conditions of Hoca Hasan Masjid and Taş Masjid, which were selected as examples among Konya neighborhood masjids for having both functions as speech and religious musics. Acoustic comfort analysis of the masjids was evaluated by acoustic simulation method through mathematical data. In this context, three-dimensional modeling of the masjids was rendered and transferred to ODEON. Acoustic simulation was performed by making sourcereceiver points, materials, optimum value acceptances. In the light of the determined actions and room acoustic parameters, simulation results were examined separately and then the results of the analysis were compared with each other. As a result, implications and suggestions regarding the acoustic conditions of the masjids in the neighborhood are articulated.
\end{abstract}

\section{Giriș}

Kültürel miras olarak kabul edilen tarihi yapıların koruma çalışmalarında genellikle yapısal ve mimari özellikler ön planda tutulmaktadır. Ancak son zamanlarda görsel algılamaya dayalı koruma anlayışına ek olarak, insanın mekân algısını oluşturan hacmin akustik özellikleri ve konfor analizi işitsel 
miras kavramı içinde yer almaya başlamıştır. Yapılan akustik belgeleme çalışmaları mimari koruma alanına da yenilik getirmiştir. Bu anlamda yapılan çoğu araştırma akustik konfor analizini inceleme ve akustik açıdan kusurlu olduğu düşünülenlere iyileştirme çalışmaları gerçekleştirmeyi amaçlamaktadır.

İslam coğrafyasında Müslümanların ibadet mekânı olan cami ve mescit yapılarında da akustik algı, görsel algllama kadar önemli kabul edilmektedir. Önde gelen İslam sanat tarihçilerinden biri olan Oleg Grabar (1983), İslam kültürünün, kendini temsil aracı olarak, "görsellik" ten çok "işitsellik" i benimsediğini, şekilden ziyade ses ve yaşanmışlığın önemli olduğunu söylemektedir [1].

Hz. Muhammet (sav) döneminden itibaren, yapılı çevrenin en önemli öğelerinden biri olan mescitler hem toplumsallı̆̆ın (cemaat ile namaz kılmak), hem de birlik ve beraberlik hissinin (Kur'an-ı Kerim'in okunması; mevlit, ilahiler vb.) önem kazandığı yapılardır. Farklı zaman ve coğrafyalarda ibadetin yanı sıra eğitim-öğretim, toplanma gibi sosyal işlevlerde üstlenebilen bu yapılar akustik açıdan incelendiğinde hem konuşma hem de dini musiki işlevini taşıyan mekanlardır.

Cemaatle kılınan namazdaki emirler ile Cuma ve bayram günleri verilen hutbe ya da vaaz konușma işlevini; bazı dini özel günlerde söylenen ilahiler dini musiki işlevini oluşturmaktadır. $\mathrm{Bu}$ bağlamda mescitlerin içerisinde gerçekleşecek işleve göre farklı akustik gereksinimleri karşılamaları beklenmektedir ve akustik açıdan değerlendirilmeleri de önem taşımaktadır.

Literatürde tarihi ve yakın dönem modern camilerin akustik performansları ile ilgili yapılan çalışmalar bulunmaktadır. En önemli çalışmalardan biri Zerhan Yüksel Can'ın koordinatörlüğünde gerçekleștirilen CAHRISMA (Sinan Camilerinin Akustik Özelliklerinin Tanımlanması ve Yeniden Canlandırılması Yolu ile Akustik Mirasın Korunması) Araştırma Projesi'nde Bizans Dönemi Kiliseleri ve Mimar Sinan Camileri üzerinde alan ölçümleri, simülasyon ve anket çalışmaları yapılarak akustik performansları değerlendirilmiştir.

Abdou [2], çalışmasında Suudi Arabistan'daki farklı boyut ve mimari özellikteki 21 adet caminin akustik özelliklerini boş ve dolu olduğu senaryolara göre incelemiş, dolu caminin boş camiye oranla akustik koşullarının daha iyi olduğu sonucuna ulaşmıştır. Kayılı [3], araștırmasında Osmanlı cami mimarisinde yapılan akustik çözümlerden ve önerilen optimum parametre değerlerinden; Orfalı [4], kitabında camilerin tarihsel gelişim sürecinden, akustik değerlendirilmesinde kullanılacak kriterler ve optimum kabul değerlerinden bahsetmişlerdir. Gül vd. [5], makalelerinde Süleymaniye Camii'nin mimari elemanlarının, malzemelerinin ve geçmişten günümüze geçirdiği onarımların hacim akustiğine etkilerini araştırmıştır. Son dönemde yapılan onarımların camiinin orta ve yüksek frekanslarda akustik konforu arttırdığı sonucuna varılmıştır.

Tez çalışmalarından Kaygısız [6], Mimar Sinan Camilerinden Şemsi Ahmet Pașa Camii ve Tip 3 Camii'nin akustik konfor koşullarını ölçüm ve simülasyon yöntemleri ile irdelemiş ve birbiri ile karşılaştırmıştır. Değerlendirme sonucunda camilerin tasarımında akustik koşulları etkileyen hususlar belirtilerek öneriler hazırlamıştır.

Kültürel miras olarak tanımlanan Anadolu Selçuklu dönemi mahalle mescitleri hem başkent Konya'daki plan tipolojileri hem de özgün mimari örnekleri ile bulundukları alanların kimliğini değiştiren ve kentsel mekân kalitesini yükselten yaplar olarak göze çarpmaktadır. Aynı zamanda Türk cami mimarisinin gelişimine öncü olarak mimarlık tarihi açısından ayrı bir önem taşımaktadır. Literatür incelendiğinde söz konusu Konya mahalle mescitlerinin yapısal ve mimari özelliklerine ait araştırmaların bulunduğu görülmekte, ancak yapıların akustik performanslarına dair araştırmalara rastlanmamaktadır. $\mathrm{Bu}$ tarihi mahalle mescitlerinin akustik konforlarının değerlendirilmesi, akustiğini olumsuz etkileyen müdahalelerin tespiti ve iyileştirme önerileri bu mirasın gelecek kuşaklara aktarılması açısından önem arz etmektedir.

Çalışmada Konya kültürel mirası için önemli olan tarihi mahalle mescitlerinin mimari özelliklerinin koruma çalışmalarına ek olarak, akustik özelliklerinin olumlu ve olumsuz yönlerinin belirlenmesi amaçlanmıştır. Bu bağlamda şehir merkezinde yer alan mahalle mescitlerinden; mimari özellikleri birbirinden farklı olan Hoca Hasan Mescidi ve Taş Mescit seçilmiştir. Temsil değeri yüksek olan bu iki mescidin simülasyon programı (ODEON 14.05 Auditorium) aracığıyla akustik konfor analizlerinin yapılması ve birbirleriyle karşılaștırmalı değerlendirilmesi hedeflenmiștir. Yapılan analizlerden elde edilen bulgular sayesinde çözüm önerilerine gidilmiştir.

\section{Materyal ve Metot}

Çalışma kapsamında örneklem olarak Anadolu Selçuklu dönemi Konya mahalle mescitleri arasından Hoca Hasan Mescidi ve Taş Mescit seçilmiştir. Bu mescitlerin seçilmesinde; şehir merkezinde önemli bir konumda bulunmaları (Sekil 1), dönemin mescit mimarisinin genel karakteristik özelliklerini taşımaları, belirli düzeyde arka plan gürültüsüne sahip olmaları, tek kubbeli ve kare formlu harim bölümüne sahip olmaları, karşılaştırma yapabilmek için plan şeması, yapı malzemesi ve kubbeye geçiş elemanı açısından birbirlerinden farklı olmaları gibi nedenler etkili olmuştur. 


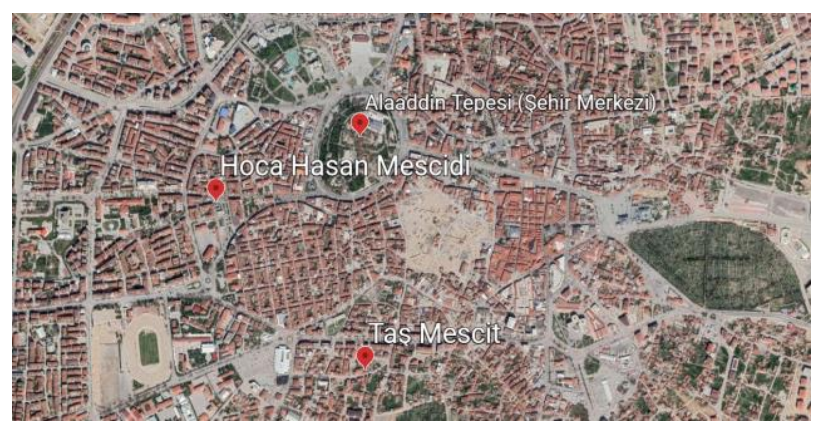

Şekil 1. Hoca Hasan Mescidi ve Taş Mescit'in konumları [13]

\subsection{Alan çalışması olarak seçilen mescitlerin özellikleri}

Bu bölümde çalışma alanı olarak seçilen Hoca Hasan Mescidi ve Taş Mescit' in yapısal ve mimari özellikleri hakkında bilgi verilmiştir.

\subsubsection{Hoca Hasan Mescidi}

Hoca Hasan Mescidi, Konya'nın Meram ilçesinde, şehir merkezine yakın konumda ve kaynaklardan edinilen bilgilere göre, Selçuklu Sultanı II. Kılıçarslan'ın Veziri Hoca Hasan tarafindan yaptırılmış olduğu bilinmektedir [7]. İnşa tarihi kesin olarak belli olmayıp, günümüzde de orijinal işlevine devam eden mescidin mimari özelliklerine bakılınca XIII. Yüzyılın ortalarında yapılmış olduğu düşünülmektedir [8].

Hoca Hasan Mescidi, Selçuklu devri üç mekânlı mescitler grubunda olup, kare planlı harim, yarı açık mekân olan son cemaat mahalli (medhal) ve minare bölümlerinden oluşmaktadır (Şekil 2). Yapıda malzeme olarak duvarların alt kismında moloz ve kesme taş, üst kısmında tuğla malzeme kullanılmıştır. Harim bölümünün üzeri kurşun kaplı tek kubbe ile son cemaat mahallinin üzeri ise sonradan eklenmiş kurşun kaplı, tek yöne eğimli çatı ile örtülmüştür [9].

Mescide giriş ve son cemaat mahalli, kuzey cephesinde yer almaktadır. Son cemaat mahalli dikdörtgen planlı, su basman üzerinde yükseltilmiş, üç bölmeli yarı açık bir mekân olup, günümüzde bir kısmı hanımlar bölümü olarak kullanılmaktadır [10].
Ayrıca bu bölümde sırlı ve sırsız tuğladan inşa edilen sivri kemerli bir mihrap ve mescidin bânisinin yattığı söylenen ahşap sandukalı bir mezar da bulunmaktadır (Şekil 3) [11].

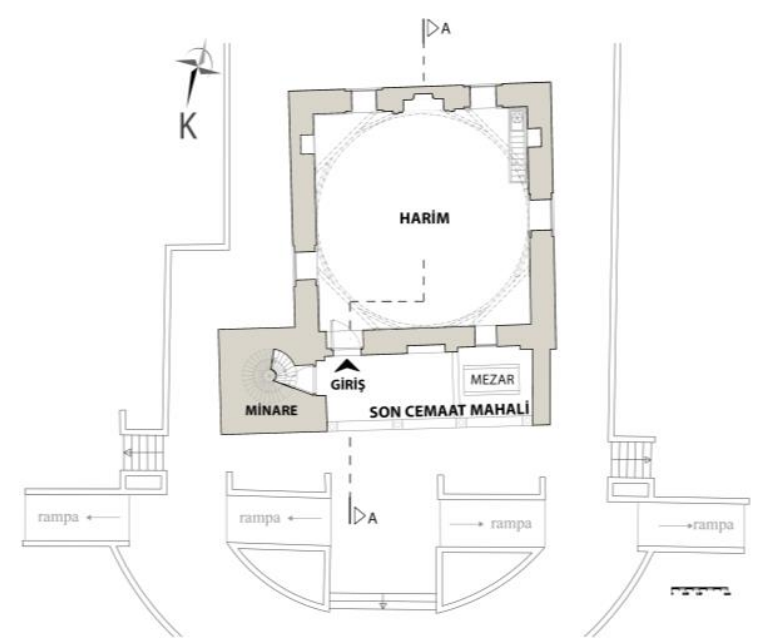

Şekil 2. Hoca Hasan Mescidi planı [12]

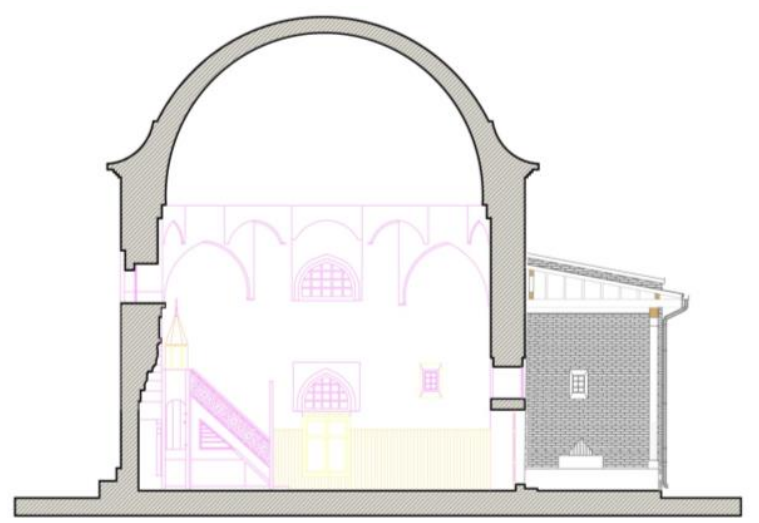

Şekil 3. Hoca Hasan Mescidi A-A kesiti[12]

Kuzey cephesinde yer alan ahșap kapıdan girilen harim bölümünün üzeri çift cidarlı tuğla kubbe ile örtülüdür ve hali hazırda sıva ile kaplanmıştır. Kubbeye geçiș üçlü tromp sistemi ile sağlanmıș ve malzeme olarak da tuğla kullanıldığı belirlenmiştir. Ayrıca harimi oluşturan tüm duvarların iç yüzeyleri sıvalı olup, kıble duvarında kavsarası mukarnaslı, muhdes, alçıdan mihrap ve muhdes ahşap bir minber yer almaktadır (Şekil 4) [7].
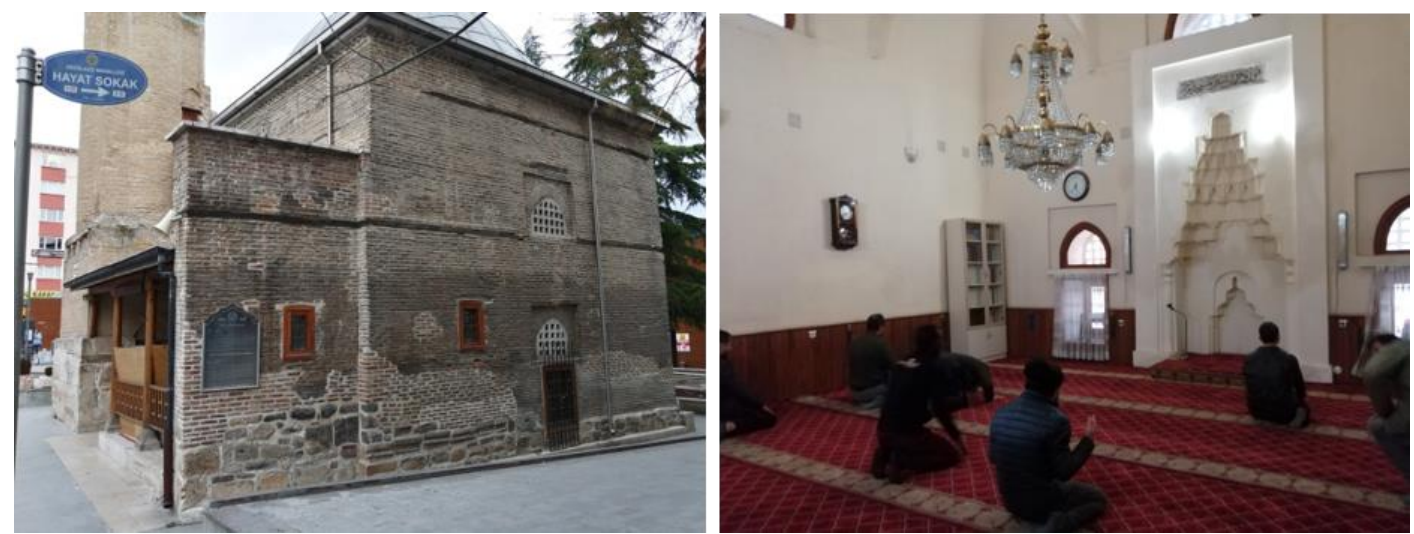

Şekil 4. Hoca Hasan Mescidi giriş cephesi ve iç mekanı [13] 


\subsubsection{Taş Mescit}

Taş Mescit şehir merkezi yakınına, $612 \mathrm{H} / 1215$ yılında İzzeddin Keykavus döneminde Hacı Ferruh bin Abdullah tarafindan Mimar Ramazan Bin Güneş'e yaptırılmıştır [11]. Yapıyı oluşturan iç ve dış tüm duvarların tamamının kesme taş, yüzey ve birleşimlerinin düzgün olması ile Akçe Gizlenmez Mescidi olarak da adlandırılmaktadır [10].

Günümüzde orijinal işlevine devam eden Taş Mescit, Selçuklu devri iki mekanlı mescit tipolojisinde olup, kare harim bölümü ve kapalı medhal bölümünden oluşmaktadır (Şekil 5) [10]. Kare plana sahip olan harim kısmı tek kubbe ile medhal bölümü ise tonozla örtülmüştür. XIII. Yüzyıl Konya mescitleri içinde, kubbe ve kubbeye geçiş elemanları da dahil olmak üzere tamamen kesme taştan inşa edilmiş tek örnek olma özelliği taşımaktadır [9].

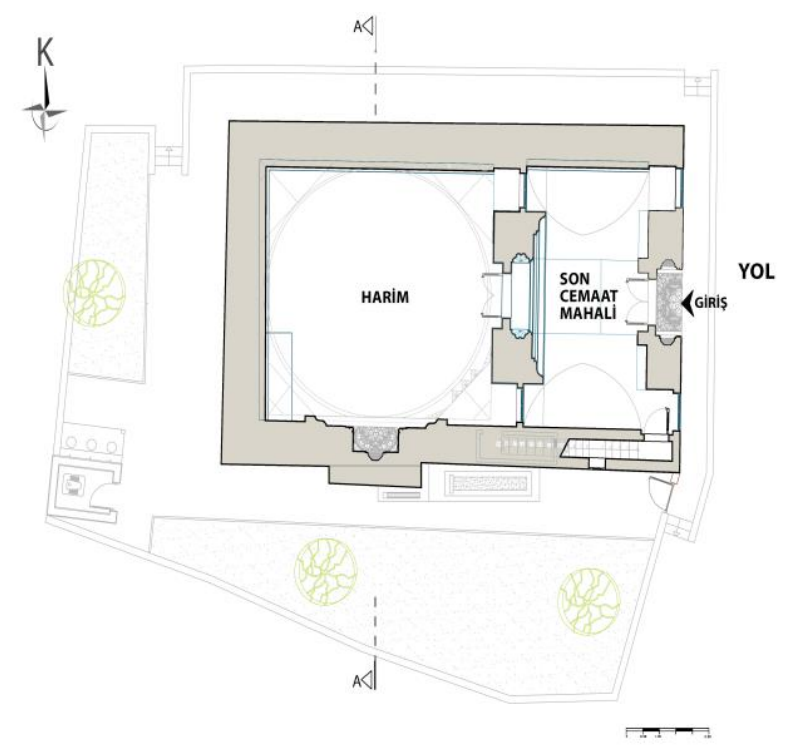

Şekil 5. Taş Mescit planı [12]

Mescidin medhal bölümüne giriș, yol kotundan aşağıda ve doğu cephesinde yer alan mukarnaslı taç kapı tarafından sağlanmaktadır. Mescidin batı ve kuzey cepheleri sağır olup; güney cephesinde, medhal duvarı içinde çatıya çıkıșı sağlayan taş bir merdiven yer almaktadır [12]. Kare planlı harim bölümüne

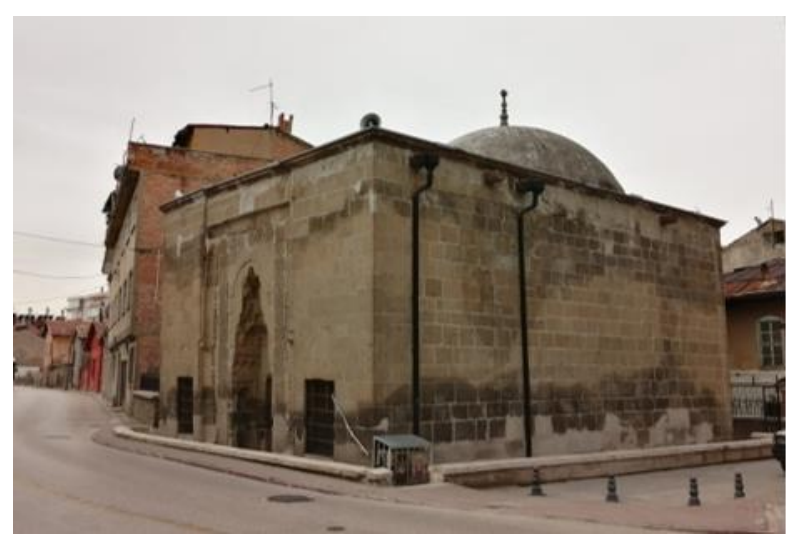

Şekil 7. Taş Mescit giriş cephesi ve iç mekanı [13] giriş, medhal bölümünün batısında yer alan, iç kısımdaki taç kapıdan sağlanmaktadır (Şekil 6). Harim bölümünün üzeri tek kubbe ile medhal bölümünün üzeri ise tonozla örtülmüștür. Kubbeye geçiş, tekli tromp sistemiyle yapılan dört trompla alt yapı sekizgene dönüştürülerek sağlanmıștır [9]. Kıble duvarında dış çerçevesi kubbe eteğine kadar yükselen kavsarası mukarnaslı orijinal mihrap nişi, güney ve batı duvarının birleştiği köşede ise sonradan eklenen muhdes ahșap bir minber bulunmaktadır (Şekil 7). Günümüzde medhalin bir bölümünde kadınlar mahfili, mescidin güney duvarı tarafinda bir mezar yer almaktadır.

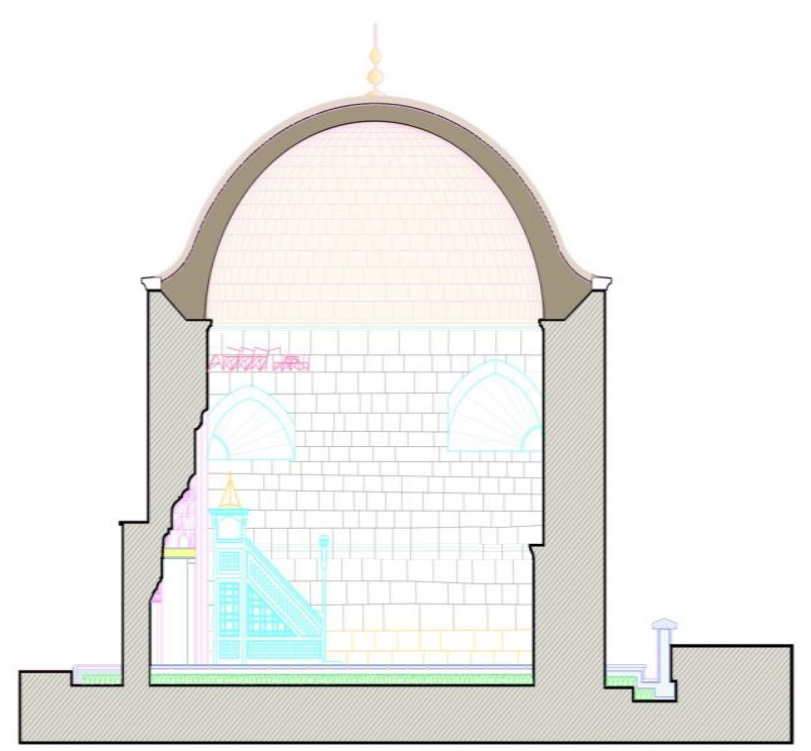

Şekil 6. Taş Mescit A-A kesiti[12]

\subsection{Metot}

Çalışmanın amacı ve kapsamına uygun seçilen mahalle mescitlerinin akustik konfor analizi matematiksel veri metodu kullanılarak akustik simülasyon yöntemi ile değerlendirilmiştir. Bu yöntem hacim akustiği analiz çalışmalarında geleneksel yöntemlerden ziyade ekonomik olması, tekrarlanabilir ve detaylı incelemelerin yapılması, daha kısa sürede sonuca ulaşılabilmesi ve sonuçların daha rahat görülebilmesi nedenlerinden dolayı günümüzde daha sık kullanılmaya başlanmıştır [15].

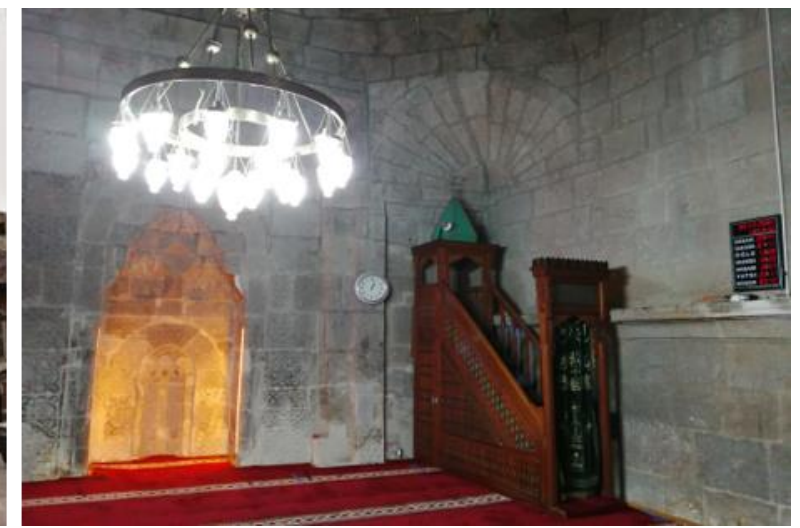


Bu bağlamda mescitlerin Sketch Up programıla üç boyutlu modellemeleri yapılarak, akustik simülasyon programı (ODEON 14.05 Auditorium) ile analizi yapılmıştır. Belirlenen eylemler (Cuma hutbesi ve Cuma namazı) ve hacim akustiği parametreleri (RT, EDT, D50, C50, C80 ve STI) Işığında elde edilen sonuçlar; grafik, şekil ve çizelgeler üzerinden açıklanmıştır. Mescitlerin mevcut durum tespiti yapılmış ve bulgular üzerinde korelasyon (karşılaştırma, değerlendirme, yorumlama) yöntemleri kullanılmıștır. Böylece elde edilen veriler doğrultusunda mescitlerde yer alan eylemler, alıcıkaynak noktalarının konumları ve farklı yapı malzemeleri gibi özelliklerin akustik performansları üzerindeki etkileri ile ilgili bulgular tespit edilmiştir. Genel olarak mahalle mescitlerinin akustik konfor koşulları için çözüm önerileri oluşturulmuştur.

\subsubsection{Simülasyon çalışmasının kabulleri}

Hoca Hasan Mescidi ve Taş Mescit' in akustik performansının hesaplanabilmesi için, simülasyon ayarları, yüzey malzemeleri, ses kaynağı-alıcı noktası özellikleri ve parametrelerin optimum değer aralıkları ile ilgili kabuller yapılmıştır.

Mescitlere ait hazırlanan modeller ODEON 14.05 Auditorium akustik simülasyon programına aktarılmış, modellerde üst üste çakışan yüzey olmadığı, analiz için gerekli ışınların model dışına kaçmadığı görülmüştür. Modellerin uygunluğu kontrol edildikten sonra hesap parametreleri belirlenmiştir. Bir ışının maksimum yansıma süresi (impulse response lenght) $7000 \mathrm{msn}$, geç ışın sayısı (number of late rays) 20000, bir ışının maksimum yansima sayısı (maximum reflection order) 10000, sanal kaynakların yansıma derecesi (transition order) 2, erken ışın sayısı (number of early rays) 10000 , arka plan gürültü seviyesi NC 25, ortam sıcaklığı $20{ }^{\circ} \mathrm{C}$ ve nem \%50 olarak tanımlanmıştır. Model yüzeylerine malzeme seçimleri için ODEON malzeme kütüphanesinden ya da literatürden yararlanılmış, malzemenin formuna ve detaylarına uygun saçıcılık değerleri belirlenmiştir.

Çalışmada cemaatin tamamen dolu olduğu kabul edilerek, Cuma namazı ve Cuma hutbesi eylemleri ele alınmış, eylemlere göre değișen ses kaynağı (S1-S2) ve 6'şar alıcı noktası (R1-R6) belirlenmiştir. Mescitlerde yer alan eylemlerde imamlar erkek olduğu için, simülasyonda erkek konuşmacı ve yüksek sesli konuşma seviyesi sağlayan "Tlkraise_NATURAL.SO8" ses kaynağı tanımlanmıştır. Alıcı noktaları için mescitlerde 0,60×1,20 m' lik birimler ayrılarak saf düzeni oluşturulmuş ve en yakın yansıtıcı yüzey ile arasının $1 \mathrm{~m}$ olmasına dikkat edilmiştir. Aynı zamanda iki mescidi karşılaştırma yapabilmek için alıcı noktaları, harim içerisinde kubbe merkezine göre aynı konuma yerleştirilmiş, yerden yükseklikleri ise değişkenlik göstermiştir. Şekil 8'de Hoca Hasan Mescidi ve Taş Mescit' in kaynak ve alıcı nokta konumları plan düzleminde verilmiştir.

Cuma hutbesi eyleminde ses kaynağı olan imam minber üzerinde, yönü cemaate dönük ve zeminden 2,85 m yüksekliğinde; alıcı noktaları da zeminden $0,80 \mathrm{~m}$ yükseklikte olarak tanımlanmıștır. Cuma namazı eyleminde ise ses kaynağı mihrap önünde, yönü kıbleye dönük ve zeminden yüksekliği 1,60 m; alıcı noktaları da kıble yönünde ve yerden yükseklikleri ayakta duran insan seviyesi olan 1,60 m tanımlanmıştır.

Çalışma kapsamında mescitlerde sırasıyla hacim akustiği parametrelerinden RT, T30, EDT, D50, C50, C80 ve STI parametreleri hesaplanmıştır. Parametrelerin değerlendirilmesinde literatürden elde edilen optimum kabul değerleri kullanılmıştır. Bahsedilen parametreler için kabul edilen optimum değer aralıkları Tablo 1'de verilmiştir.

Konuşma amaçlı eylemlerden olan Cuma hutbesi eyleminde alçak ve yüksek frekanslarda optimum çınlama sürelerinin orta frekanslarla eşit olduğu; dini musiki amaçlı eylemlerden olan Cuma namazı eyleminde ise orta ve yüksek frekanslarda eşit, alçak frekanslarda \%20 artış olduğu kabul edilmiştir. Her iki eylemde de RT parametresinin optimum değer aralığı için alt ve üst sınır $\pm \% 10$ olarak verilmiştir. Tüm parametrelerde alıcı noktaları arasında değerlendirme ve karşılaştırma yapabilmek için konuşmada anlaşılabilirliğinin en etkili olduğu orta frekans $(1000 \mathrm{~Hz})$ değerleri kullanılmıştır. Sadece çınlama süresi parametresinde genel değerlendirme için RT değerleri incelenmiştir.

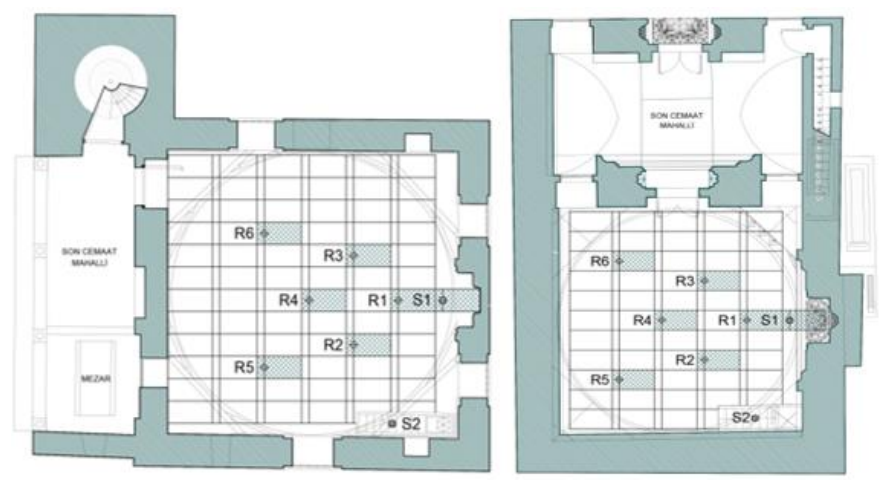

Şekil 8. Mescitlerin plan düzleminde kaynak-alııı nokta konumları Solda Hoca Hasan Mescidi/ Sağda Taş Mescit [13] 
Tablo 1. Mescitler için hacim akustiği parametrelerinin optimum değer kabulleri

\begin{tabular}{|c|c|c|c|}
\hline $\begin{array}{l}\text { HACIMM AKUSTİĞİ } \\
\text { PARAMETRELERİ }\end{array}$ & \multicolumn{2}{|c|}{ MESCITLER İÇİN OPTIMMUM DEĞER KABULLERİ } & KAYNAK \\
\hline Çınlama Süresi (RT) & $\begin{array}{c}\text { Hoca Hasan Mescidi } \\
\mathrm{V}=550 \mathrm{~m}^{3} \\
\mathrm{RT}=1.61 \mathrm{sn}\end{array}$ & $\begin{array}{c}\text { Taş Mescit } \\
\mathrm{V}=375 \mathrm{~m}^{3} \\
\mathrm{RT}=1.55 \mathrm{sn}\end{array}$ & {$[6,16]$} \\
\hline Erken Düşme Süresi (EDT) & \multicolumn{2}{|c|}{ EDT/RT=1.1, RT $-(\% 10 x$ RT $) \leq \mathrm{EDT} \leq \mathrm{RT}+(\% 10 \mathrm{x} \mathrm{RT})$} & [17] \\
\hline Ayırt Edilebilirlik (D50) & \multicolumn{2}{|c|}{ Konuşmanın anlaşılabilirliği için D50>0.50 } & [18] \\
\hline Netlik (C80-C50) & $\begin{array}{cc}\text { C80 (Müzik) } & -4 \mathrm{dl} \\
\text { C50 (Konuşma) }\end{array}$ & $+4 \mathrm{~dB}$ & $\begin{array}{l}{[19]} \\
{[18]}\end{array}$ \\
\hline Konuşma İletim İndeksi (STI) & $\begin{array}{r}\text { 0- 0,30 kötü/ 0,30-0,45 zayıf/ 0,45-0,6 } \\
0,60-0,75 \text { iyi/ } 0,75-1,00 \text { müke }\end{array}$ & edici/ & {$[19,20]$} \\
\hline
\end{tabular}

\section{Bulgular}

Bu bölümde Hoca Hasan Mescidi ve Taş Mescit' in akustik simülasyon sonuçlarına ve birbirleriyle karşılaştırmalı değerlendirilmesine yer verilmiştir.

\subsection{Hoca Hasan Mescidi' nin akustik konfor analizi}

\subsubsection{Cuma hutbesi eylemi}

Çınlama süresi (RT) ve erken düşme süresi (EDT) bir hacmin akustik özelliklerini belirlemek için kullanılan en önemli parametrelerdendir. Akustik açıdan RT değeri uzun olan hacimler canlı, RT değeri kısa olan hacimler ise ölü-kuru olarak tanımlanmaktadır. Kısa EDT değerleri sesin açıklığını artırırken, uzun EDT değerleri ise sesin maskelenmesine neden olarak konuşma anlaşılabilirliğini azaltmaktadır [6].

$550 \mathrm{~m}^{3}$ hacme sahip Hoca Hasan Mescidi' nin orta frekanslar için optimum çınlama süresi 1,61 sn' dir. Cuma hutbesi eyleminde optimum çınlama sürelerinin tüm frekanslarda eşit olduğu ve değer aralığı için alt ile üst sınır 1,44-1,77 sn kabul edilmiştir. Şekil 9' da Cuma hutbesi eylemi için simülasyon sonucunda $125-4000 \mathrm{~Hz}$. arasında elde edilen çınlama süreleri ve optimum kabul değerleri verilmiştir.

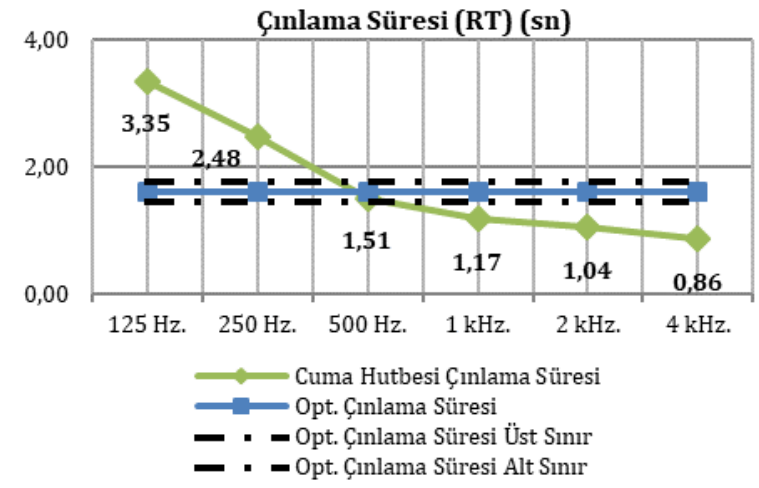

Şekil 9. Hoca Hasan Mescidi- Cuma namazı eylemi için elde edilen RT değerleri

Grafik incelendiğinde, alçak frekanslarda kabul edilebilir değer aralığının üzerinde değerler elde edilirken, orta ve yüksek frekanslarda (500 Hz. hariç) düşük değerler elde edilmiştir. Hoca Hasan Mescidi 75 kişi kapasitesi olan küçük ölçekli bir mescit olup, Cuma hutbesi eyleminde mescidin tamamen dolu olması, yüksek frekanslara gidildikçe özellikle cemaatin ve havanın yutuculuk değerlerinin oldukça artması sebebiyle çınlama sürelerinde azalma gözlemlenmiştir. Şekil 10’ da Cuma hutbesi eylemi için bütün alıcı noktalarının $1000 \mathrm{~Hz}$. frekans değerlerinden belirlenen EDT/T30 oranları verilmiştir.

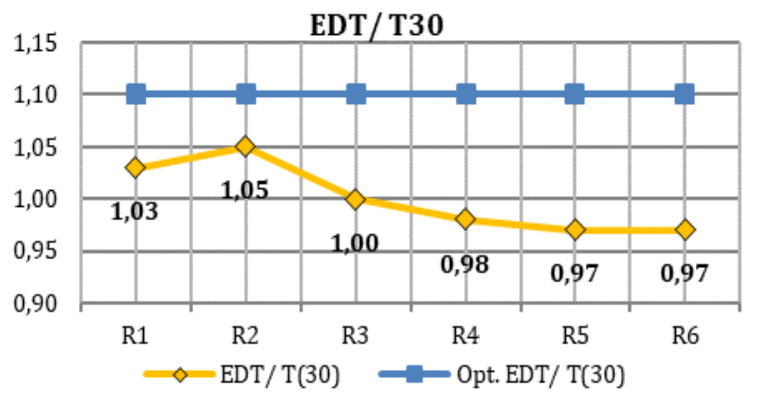

Şekil 10. Hoca Hasan Mescidi- Cuma hutbesi eylemi için EDT/T30 değerleri (1000 Hz.)

Elde edilen değerler incelendiğinde tüm alıcı noktalarında EDT/T30 oranının optimum değer olan 1,1' den düşük değerler elde edildiği görülmektedir. T30 değerleri birbirine yakın değerler aldığı için alıcı noktaları arasındaki EDT/T30 oranı farkını EDT parametresi belirlemektedir. En yüksek değer duvar ve kubbe yüzeylerinden gecikmiş yansımalar ulaşan R2 alıcı noktasında; en düşük değer ise yüksek enerjili erken yansımalar alan R6 alıcı noktasında görülmüștür. Simülasyonda T30 ve EDT parametrelerinin $1000 \mathrm{~Hz}$. frekansı grid hesabı Şekil 11 ' de verilmiştir.

T30 parametresi incelendiğinde, mescitte genel olarak düșük değerler elde edilirken, mescidin sağarka köşesine ulaşan çok sayıda ve yüksek enerjili geç süreli erken yansımalar nedeniyle yüksek değerler görülmektedir. EDT grid hesabı incelendiğinde, mescidin sol-arka kısmına ve mihrap aksı ile minber arasındaki kısımlara ulaşan erken yansımaların az sayıda ve düşük enerjili olması nedeniyle yüksek değerler elde edilmiştir. Minberin yan kısımlarında ve mescidin arka-orta kısımlarında erken ses enerjisi hızlı bir şekilde sönümlendiği için düşük değerler görülmektedir. 

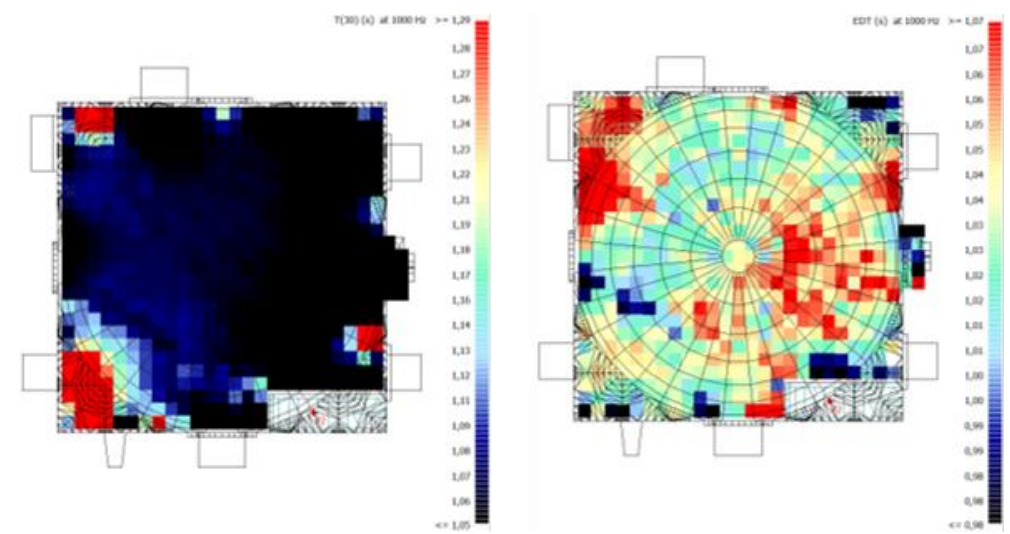

Şekil 11. Cuma hutbesi eylemi için T30 ve EDT grid hesabı $(1000 \mathrm{~Hz}$.

D50 konuşma anlașılabilirliği parametresidir. Mescitlerde konușma anlașllabilirliğinin yüksek olması için bu parametrenin optimum değeri 0,50 ve üzeri kabul edilmektedir. Tablo 2'de alıcı noktalarında elde edilen D50 değerleri verilmiştir.

Tablo 2. Hoca Hasan Mescidi- Cuma hutbesi eylemi için bütün frekanslarda elde edilen D50 değerleri

\begin{tabular}{|c|c|c|c|c|c|c|}
\hline D50 & $\begin{array}{l}125 \\
\text { Hz. }\end{array}$ & $\begin{array}{c}250 \\
\mathrm{~Hz} .\end{array}$ & $\begin{array}{l}500 \\
\text { Hz. }\end{array}$ & $\begin{array}{c}1000 \\
\text { Hz. }\end{array}$ & $\begin{array}{c}2000 \\
\text { Hz. }\end{array}$ & $\begin{array}{c}4000 \\
\text { Hz. }\end{array}$ \\
\hline R1 & 0,17 & 0,28 & 0,47 & 0,48 & 0,64 & 0,72 \\
\hline R2 & 0,20 & 0,33 & 0,49 & 0,50 & 0,65 & 0,73 \\
\hline R3 & 0,18 & 0,27 & 0,43 & 0,47 & 0,58 & 0,67 \\
\hline $\mathrm{R} 4$ & 0,18 & 0,27 & 0,41 & 0,47 & 0,58 & 0,66 \\
\hline R5 & 0,19 & 0,30 & 0,51 & 0,56 & 0,65 & 0,75 \\
\hline R6 & 0,17 & 0,25 & 0,40 & 0,49 & 0,55 & 0,61 \\
\hline
\end{tabular}

Tablo incelendiğinde genel olarak alçak frekanslardan yüksek frekanslara gidildikçe D50 değerlerinin arttığı görülmektedir. Alçak frekanslarda tüm alıcı noktalarında optimum değer sınırı olan 0,50 değerinin altında, orta frekanslarda optimum değere yakın, yüksek frekanslarda ise optimum değerin üzerinde elde edilmiştir. $1000 \mathrm{~Hz}$ ' de alıc $^{\prime}$ noktalarında elde edilen değerler incelendiğinde, genel olarak kaynak noktasına yakın ve yüksek enerjili erken yansımalar ulaşan alıcı noktalarında daha yüksek değerler elde edilmiştir. En yüksek değerler R5 alıcı noktasında, en düşük değerler sırasıyla R3 ve R4 alıcı noktalarında görülmektedir. Simülasyonda Cuma hutbesi eylemi için D50 parametresinin $1000 \mathrm{~Hz}$. frekansinda grid hesabı Şekil 12' de gösterilmiştir.

Grid hesabı incelendiğinde, konuşma yönü doğrultusunda, minbere yakın bölümler ile mescidin sağ-arka bölümlerinde D50 değerlerinin yüksek olduğu görülmektedir. Minbere yakın bölümlerde direkt ses enerjisinin yüksek olması, diğer bölümlerde ise mescidin küçük hacimli olması nedeniyle hem arka ve yan duvarlardan hem de tromp yüzeyinden gelen yüksek enerjili ve çok sayıda erken yansımalar alması etkili olmuştur. Minberin akustik gölge oluşturduğu ve mescidin sağ-arka köşesi ile sol ön bölümlerinde düşük değerler elde edilmiştir. Gölgede kalan bölümlere direkt ses ulaşmadığı, diğer bölümlere ise tüm yüzeylerden çok sayıda ve yüksek enerjili gecikmiş yansımalar ulaşmaktadır. Sonuç olarak D50 değerlerinin yüksek olduğu kısımlarda konuşma anlaşılabilirliği yüksek, düşük olan kısımlarda ise düşük olması beklenmektedir.

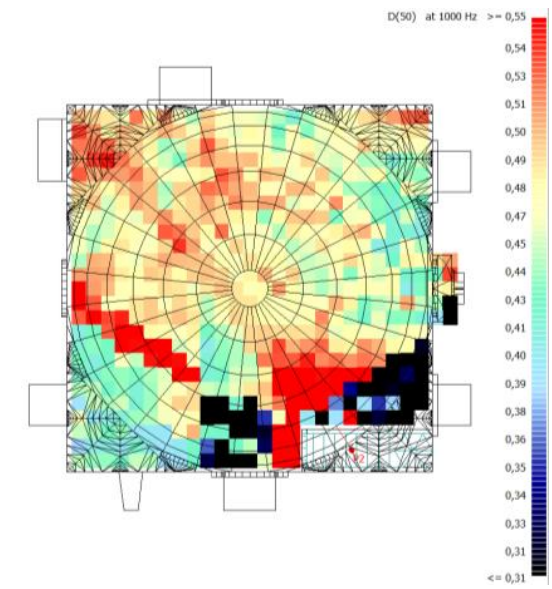

Şekil 12. Cuma hutbesi eylemi için D50 parametresi grid hesabı (1000 Hz.)

Konuşma için netlik parametresi olan C50, erken ses enerjisinin geç ses enerjisine oranı olarak ifade edilmektedir. Bu değer yükseldikçe mescitler akustik açıdan kuru hale gelerek konuşma anlaşılabilirliği artmaktadır. Değerin düşük olması ise mekânın canlı hale gelmesine ve çınlamanın artmasına neden olarak anlaşılabilirlik azalmaktadır. Mescitlerde Cuma hutbesi eylemi için C50 parametresi değerlerinin 0 dB'den büyük olması beklenmektedir. Tablo 3' de alıcı noktalarında bütün frekanslarda elde edilen C50 değerleri verilmiştir.

Tablo 3. Hoca Hasan Mescidi- Cuma hutbesi eylemi için bütün frekanslarda elde edilen C50 değerleri

\begin{tabular}{ccccccc}
\hline C50 & $\mathbf{1 2 5}$ & $\mathbf{2 5 0}$ & $\mathbf{5 0 0}$ & $\mathbf{1 0 0 0}$ & $\mathbf{2 0 0 0}$ & $\mathbf{4 0 0 0}$ \\
(dB) & Hz. & Hz. & Hz. & Hz. & Hz. & Hz. \\
\hline R1 & $-6,8$ & $-4,2$ & $-5,0$ & $-0,4$ & 2,4 & 4,2 \\
R2 & $-5,9$ & $-3,1$ & $-0,2$ & 0,1 & 2,7 & 4,4 \\
R3 & $-6,5$ & $-4,2$ & $-1,3$ & $-0,4$ & 1,4 & 3,1 \\
R4 & $-6,6$ & $-4,3$ & $-1,6$ & $-0,5$ & 1,3 & 2,8 \\
R5 & $-6,3$ & $-3,7$ & 0,1 & 1,1 & 2,8 & 4,7 \\
R6 & $-6,8$ & $-4,7$ & $-1,7$ & $-0,2$ & 0,9 & 2,0 \\
\hline
\end{tabular}

Alıcı noktalarında elde edilen C50 değerleri incelendiğinde, genel olarak bütün alıcı noktalarında alçak frekanslardan yüksek frekanslara doğru 
gidildikçe C50 değerlerinin arttığı gözlenmektedir. Bunun nedeni mescitlerde alçak frekanslarda oluşan çınlama sürelerinin, orta ve yüksek frekanslardaki çınlama sürelerine göre daha fazla olmasından kaynaklanmaktadır. Hem yüksek frekanslarda cemaatin ve havanın daha fazla yutucu olması hem de yüzeylerin alçak frekanslarda yansıtıcı olması nedeniyle çınlama süresi farklılık göstermektedir. Sonuç olarak çınlama süresi düştükçe netlik artmaktadır. Cuma hutbesi eylemi için tüm alıcı noktalarında yüksek frekanslarda optimum değerin üzerinde, pozitif değerler; alçak ve orta frekanslarda (R5 hariç) optimum değerin altında, negatif değerler elde edilmiştir.

$1000 \mathrm{~Hz}$. frekansında alıcı noktalarında elde edilen C50 değerleri incelendiğinde, direkt ses enerjisi yüksek olan R5 alıcı noktasında en yüksek; çok sayıda ve yüksek enerjili geç süreli erken yansımalar ulaşan R4 alıcısında da en düşük değerler görülmektedir.

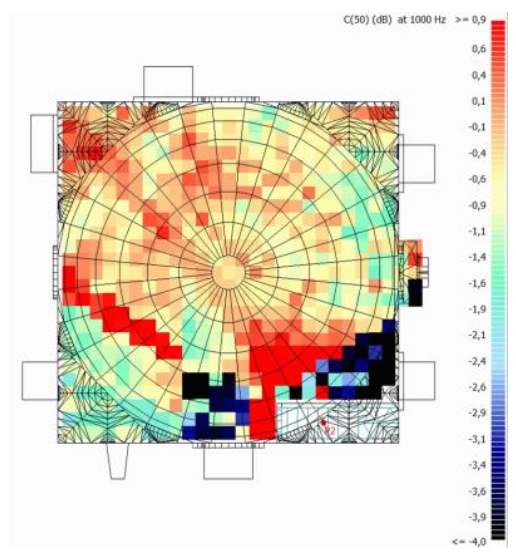

Şekil 13. Cuma hutbesi eylemi için C50 parametresi grid hesabı $(1000 \mathrm{~Hz}$.

C50 parametresinin Şekil 13' de verilen grid hesabı incelendiğinde, kaynak yöneliminin ve alıcı-kaynak arasındaki uzaklığın C50 değerlerinde etkili olduğu görülmüştür. Mescitte kaynağın konuşma yönü doğrultusu ve minbere yakın bölümler ile mescidin sağ-arka bölümlerinde C50 değerlerinin yüksek olduğu görülmektedir. Minberin akustik gölge oluşturduğu, duvarlardan ve tromp yüzeyinden yüksek enerjili gecikmiş yansımalar ulaşan bölümlerde düşük C50 değerleri elde edilmiştir.

Diğer bir konuşma anlaşılabilirliği parametresi olan STI parametresinde, mescitlerde ses kaynağı olan imamın erkek olması nedeniyle STImale değerleri incelenmiştir. Bu parametrede 0,45-0,60 arası tatmin edici, 0,60-0,75 arası iyi, 0,75' den büyük değerler ise mükemmel olarak nitelendirilmektedir. Değer yükseldikçe konuşma anlaşlabilirliği de artmaktadır. Şekil 14' de bütün alıcı noktalarında elde edilen STImale değerleri verilmiştir.

Grafik incelendiğinde, alıcı noktalarında 0,58-0,62 aralığında birbirine yakın değerler ve konuşma anlaşılabilirlik seviyesinin tatmin edici olduğu görülmektedir. En yüksek değerler ses kaynağına yakın ve güçlü erken yansımaların ulaştığı R2 ve R5 alıcı noktalarında iyi seviyede elde edilmiştir.

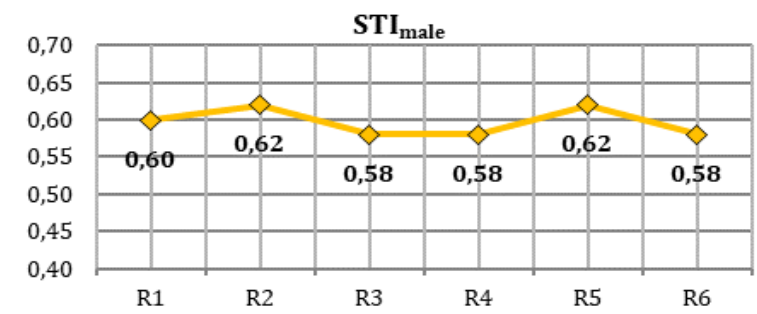

Şekil 14. Hoca Hasan Mescidi- Cuma hutbesi eylemi için elde edilen STImale değerleri

STImale parametresinin Şekil 15' de verilen grid hesabı incelendiğinde, minberin etkisiyle akustik gölgede kalan ve kubbeden gecikmiş yansımalar ulaşan bölgelerde düşük STImale değerleri elde edilmiş, aynı zamanda konuşma anlaşılabilirliğinin düșük olmasına neden olmuştur. İmamın konuşma yönü doğrultusundaki minbere yakın bölgelerde yüksek enerjili direkt sesin ulaşması; sağ- arka bölgelerde ise yakın yan ve arka duvar üzerinden erken yansımaların (0-15 msn) ulaşması nedeniyle yüksek STImale değerleri görülmüștür. Cuma hutbesi eylemi için alıcı noktalarında yüksek STImale değerlerinde konuşma anlaşılabilirliği iyi; düşük STImale değerlerinde ise tatmin edici seviye elde edilmiştir.

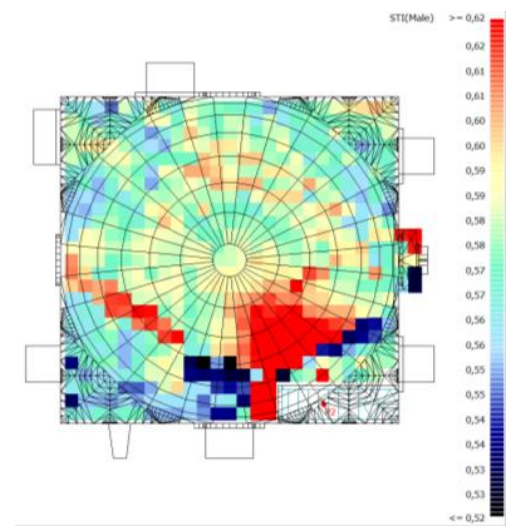

Şekil 15. Hoca Hasan Mescidi- Cuma hutbesi eylemi için STImale parametresi grid hesabı

\subsubsection{Cuma namazı eylemi}

Hoca Hasan Mescidi için orta frekanslarda optimum çınlama süresi 1,61 sn olarak hesaplanmıştır. Dini musiki amaçlı eylemlerden olan Cuma namazı eyleminde optimum çınlama süresi değerinin orta ve yüksek frekanslarda eşit, alçak frekanslarda \%20 artış olduğu kabul edilmiştir. Şekil 16' da Cuma namazı eylemi için simülasyon sonucunda elde edilen çınlama süreleri ve optimum kabul değerleri verilmiştir.

Grafik incelendiğinde, sadece $250 \mathrm{~Hz}$. ve $500 \mathrm{~Hz}$. frekanslarındaki değerler optimum değer aralığına yaklaşmıştır. Mescitte alçak frekanslarda optimum değer aralığının üzerinde çınlama süresi elde 
edilirken, orta ve yüksek frekanslarda ise optimum aralığın altında değerler elde edilmiştir. Bunun nedeni alçak frekanslarda yansıtıcı malzemelerin fazla olması ile orta ve yüksek frekanslarda toplam yutuculuğun artmasından kaynaklanmaktadır.

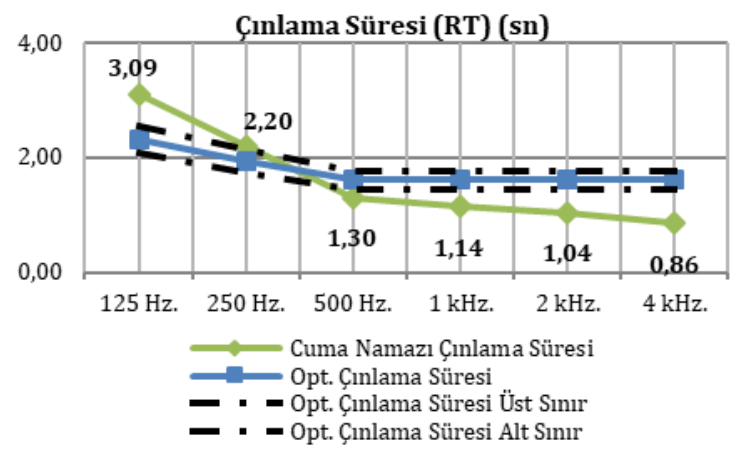

Şekil 16. Hoca Hasan Mescidi- Cuma namazı eylemi için elde edilen RT değerleri

Şekil 17'de Cuma hutbesi eylemi için alıcl noktalarının $1000 \mathrm{~Hz}$. frekans değerlerinden belirlenen EDT/T30 oranları verilmiștir. Elde edilen değerler incelendiğinde alıcı noktalarının genelinde EDT/T30 oranının optimum değer olan 1,1'den düşük değerler elde edildiği görülmektedir.

En yüksek değer cemaat ve hacim yüzeylerinden yüksek enerjili, geç süreli erken yansımalar ulaşan R4 alıcı noktasında; en düşük değer ise konumundan dolayı direkt ses enerjisi yüksek olan R1 alıcısında görülmüştür.

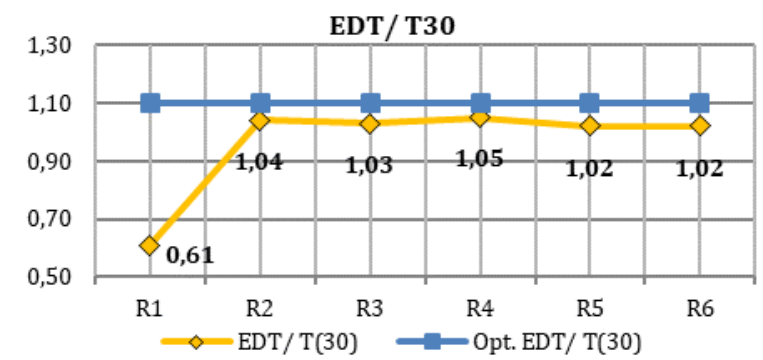

Şekil 17. Hoca Hasan Mescidi- Cuma namazı eylemi için EDT/T30 değerleri $(1000 \mathrm{~Hz}$.)
Cuma namazı eylemi için T30 ve EDT parametrelerinin $1000 \mathrm{~Hz}$. frekansı grid hesabı Şekil 18' de verilmiștir. T30 parametresi grid hesabı incelendiğinde, mescitte T30 değerlerinin birbirine yakın, ortalama değerler aldığı, nispeten mihrap aksına göre sol yan, sağ arka köșe ve mihrabın sağ yan bölümlerinde biraz yüksek değerler elde edildiği görülmektedir. $\mathrm{Bu}$ durum direkt ses enerjisinden daha yüksek enerjili erken yansımalar ve kubbe yüzeyinden gelen gecikmiş yansımalardan kaynaklanmaktadır. Düșük T30 değerleri de kaynağa yakın konumda bulunan mihrap bölgesinde, yansımaların kısa sürede gelmesiyle ortaya çıkmaktadır. EDT parametresi grid hesabı incelendiğinde ise kaynağın bulunduğu mihrap bölgesinde en düşük, mihrap aksının kaynağa yakın sağ ve sol bölgelerinde düşük değerler elde edilmiştir. Mescidin arkasına doğru, kaynaktan uzaklaştıkça EDT değerlerinde artış görülmektedir. Minberin önündeki bölge dışında mihrap aksı sağı ve solunda simetrik renk dokusu elde edilmiștir. Bu bölgenin oluşma nedeni yan duvarlardan gelebilecek erken yansımaların minber tarafindan engellemesinden kaynaklanmaktadır.

Cuma namazı eyleminde D50 parametresi için tüm alıcı noktalarında elde edilen değerler incelendiğinde, alçak frekanslarda çınlama süreleri yüksek olduğu için D50 değerlerinin düşük olduğu ve çınlama sürelerinin azalmasına bağlı olarak yüksek frekanslara gidildikçe D50 değerlerinin yükseldiği görülmektedir. Tablo 4' de alıcı noktalarında elde edilen D50 değerleri verilmiștir.

Tablo 4. Hoca Hasan Mescidi- Cuma namazı eylemi için bütün frekanslarda elde edilen D50 değerleri

\begin{tabular}{ccccccc}
\hline \multirow{2}{*}{ D50 } & $\mathbf{1 2 5}$ & $\begin{array}{c}\mathbf{2 5 0} \\
\text { Hz. }\end{array}$ & $\begin{array}{c}\mathbf{5 0 0} \\
\text { Hz. }\end{array}$ & $\begin{array}{c}\text { Hz. } \\
\text { Hz. }\end{array}$ & $\begin{array}{c}\mathbf{2 0 0 0} \\
\text { Hz. }\end{array}$ & $\begin{array}{c}\mathbf{4 0 0 0} \\
\text { Hz. }\end{array}$ \\
\hline R1 & 0,41 & 0,54 & 0,76 & 0,83 & 0,84 & 0,86 \\
R2 & 0,21 & 0,31 & 0,48 & 0,48 & 0,58 & 0,62 \\
R3 & 0,23 & 0,34 & 0,53 & 0,53 & 0,61 & 0,65 \\
R4 & 0,19 & 0,28 & 0,48 & 0,62 & 0,64 & 0,67 \\
R5 & 0,19 & 0,28 & 0,46 & 0,47 & 0,55 & 0,59 \\
R6 & 0,18 & 0,27 & 0,45 & 0,46 & 0,54 & 0,58 \\
\hline
\end{tabular}

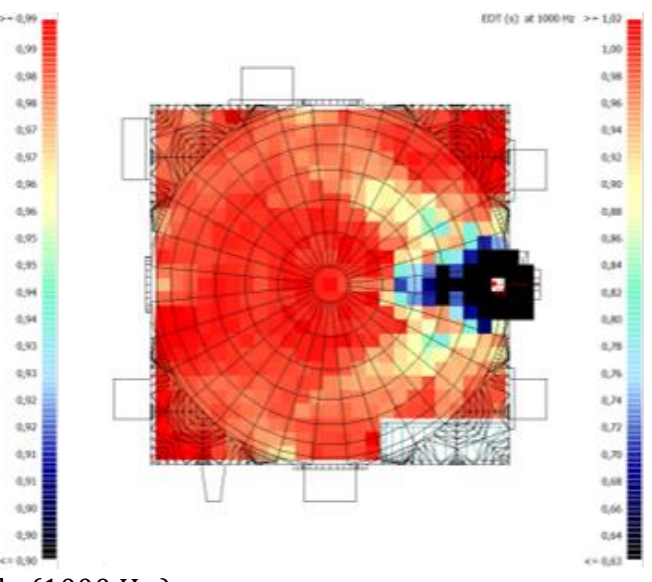

Şekil 18. Cuma namazı eylemi için T30 ve EDT grid hesabı (1000 Hz.)

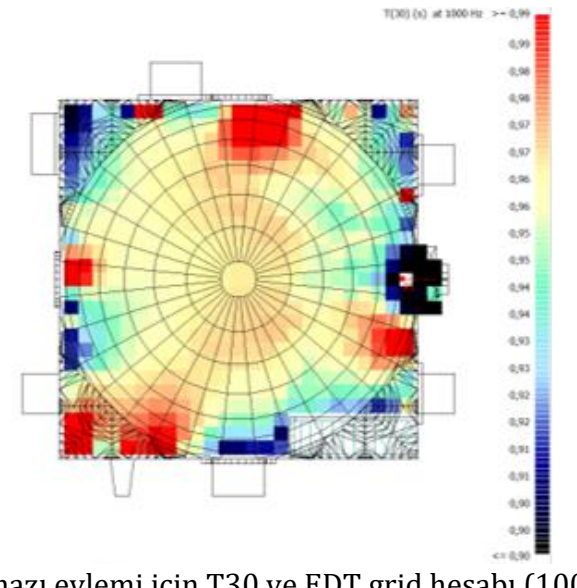


Alıcı noktalarının 1000 Hz.' de elde edilen D50 değerleri incelendiğinde, en yüksek değer çınlama süreleri düşük, kaynağa yakın konumda bulunan ve mihrap ile minber yüzeyinden güçlü erken yansımalar ulaşan R1 alıcı noktasında görülmektedir. En düşük değer ise birden fazla yüzeyden geç yansımalar ulaşan R4 alıcısında elde edilmiştir.

D50 parametresinin Şekil 19' da verilen grid hesabı incelendiğinde, kaynağa yakın konumu ve direkt ses enerjisinin yüksek olması nedeniyle mihrap çevresindeki bölümlerde en yüksek değerler elde edilmiștir. Ses kaynağından uzaklaștıkça arka kısımlara doğru D50 değerlerinde azalma görülmüştür. Genel olarak D50 parametre değerlerinde optimum değer alt sınırına yakın değerler elde edilmiştir.

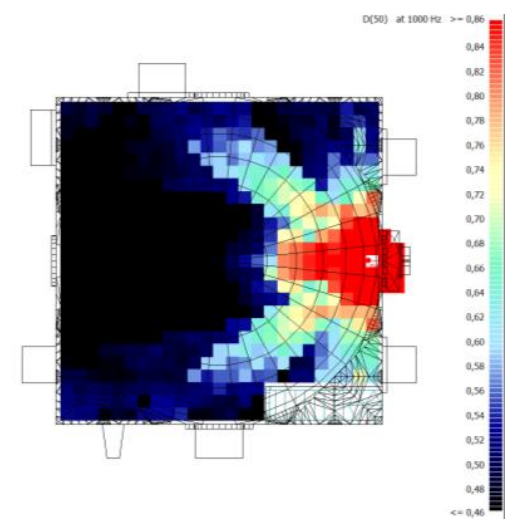

Şekil 19. Cuma namazı eylemi için D50 parametresi grid hesabı (1000 Hz.)

Dini musiki için netlik parametresi olan C80, alıcı noktasına gelen ilk $80 \mathrm{msn}$ içindeki erken ses enerjisinin, bu süreden sonra gelen geç ses enerjisine oranı olarak tanımlanmaktadır. C80 parametresi T30 değerleri ile ters orantılıdır ve optimum değer aralığı $-4 \mathrm{~dB}$ ile $+4 \mathrm{~dB}$ aralığıdır. Bu değer aralığından fazla olması seslerin ahenginin bozulmasına, düşük olması ise seslerin maskelenmesine neden olmaktadır. Tablo 5' de alıcı noktalarında elde edilen C80 değerleri verilmiştir.

Cuma namazı eylemi için alçak frekanslardan yüksek frekanslara doğru gidildikçe C80 değerlerinde artış görülmektedir. Tüm alıcı noktalarında yüksek frekanslarda optimum değer aralığının üzerinde, pozitif değerler; alçak ve orta frekanslarda optimum değer aralığı içinde değerler elde edilmiştir.

Tablo 5. Hoca Hasan Mescidi- Cuma namazı eylemi için bütün frekanslarda elde edilen C80 değerleri

\begin{tabular}{ccccccc}
\hline $\begin{array}{c}\text { C80 } \\
\text { (dB) }\end{array}$ & $\begin{array}{c}\mathbf{1 2 5} \\
\text { Hz. }\end{array}$ & $\begin{array}{c}\mathbf{2 5 0} \\
\text { Hz. }\end{array}$ & $\begin{array}{c}\mathbf{5 0 0} \\
\text { Hz. }\end{array}$ & $\begin{array}{c}\mathbf{1 0 0 0} \\
\text { Hz. }\end{array}$ & $\begin{array}{c}\mathbf{2 0 0 0} \\
\text { Hz. }\end{array}$ & $\begin{array}{c}\mathbf{4 0 0 0} \\
\text { Hz. }\end{array}$ \\
\hline R1 & $-0,5$ & 2,0 & 6,9 & 8,9 & 9,4 & 10,4 \\
R2 & $-3,9$ & $-1,4$ & 2,2 & 2,8 & 4,2 & 5,0 \\
R3 & $-3,4$ & $-0,9$ & 3,1 & 3,6 & 4,9 & 5,6 \\
R4 & $-4,3$ & $-1,9$ & 2,2 & 4,6 & 5,1 & 5,8 \\
R5 & $-4,3$ & $-2,0$ & 1,8 & 2,5 & 3,7 & 4,4 \\
R6 & $-4,5$ & $-2,0$ & 1,8 & 2,5 & 3,7 & 4,5 \\
\hline
\end{tabular}

C80 parametresinin Şekil 20'de verilen grid hesabı incelendiğinde, kaynağa yakın mihrap çevresindeki bölümlerde direkt ses enerjisinin yüksek olmasından dolayı yüksek değerler; ses kaynağından uzaklaștıkça arka kısımlara doğru C80 değerlerinde azalma görülmüştür. Genel olarak C80 parametre değerleri optimum değer aralığında elde edilmiştir. $\mathrm{Bu}$ durum mescidin namaz eylemi için uygun olduğunu ve açıktan Kur'an-ı Kerim okunurken seslerin birbirini maskelemeden, ahenk içerisinde işitileceğini göstermektedir.

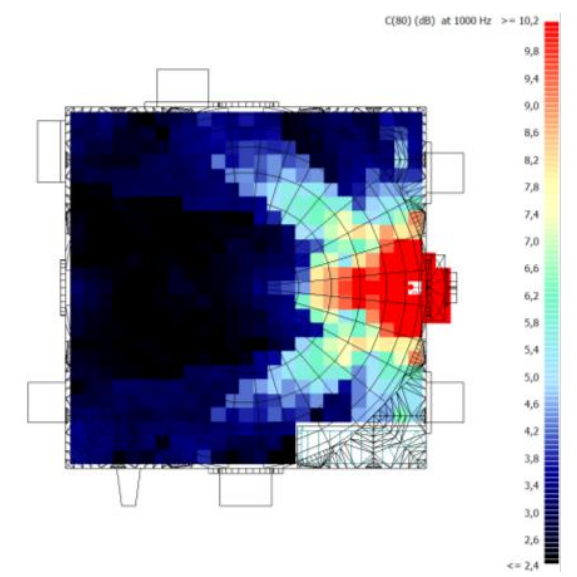

Şekil 20. Cuma namazı eylemi için C80 parametresi grid hesabı $(1000 \mathrm{~Hz}$.)

Hoca Hasan Mescidi Cuma namazı eylemi için elde edilen STI male değerleri Şekil 21' de verilmiștir.

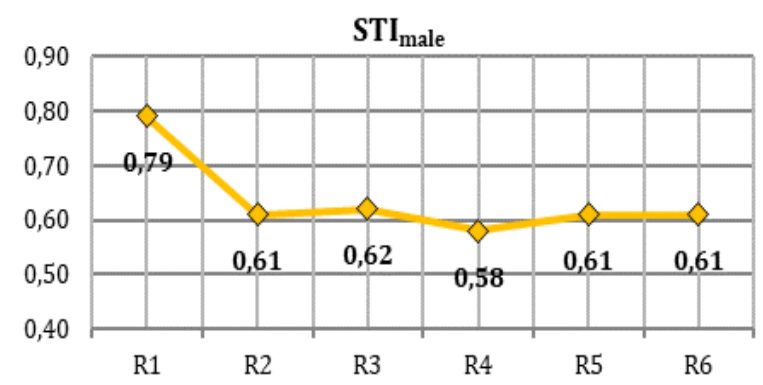

Şekil 21. Hoca Hasan Mescidi- Cuma namazı eylemi için elde edilen STImale değerleri

Grafik incelendiğinde, 0,58-0,79 aralığında değerler elde edildiği ve genel olarak konuşma anlaşılabilirlik seviyesinin iyi olduğu görülmüştür. En yüksek değer kaynak noktasına yakın olması ve mihrap ile minberden yüksek enerjili erken yansımalar alması nedeniyle R1 alıcı noktasında mükemmel seviyede elde edilmiştir. En düşük değer kubbe merkezine yakın, gecikmiş yansımalar alan R4 alıcı noktasında tatmin edici seviyede görülmektedir.

STImale parametresinin Şekil 22' de verilen grid hesabı incelendiğinde, D50 parametresi gibi kaynak noktasına yakın bölgelerde yüksek değerler, kaynaktan uzaklaștıkça düşük değerler elde edilmiştir. 


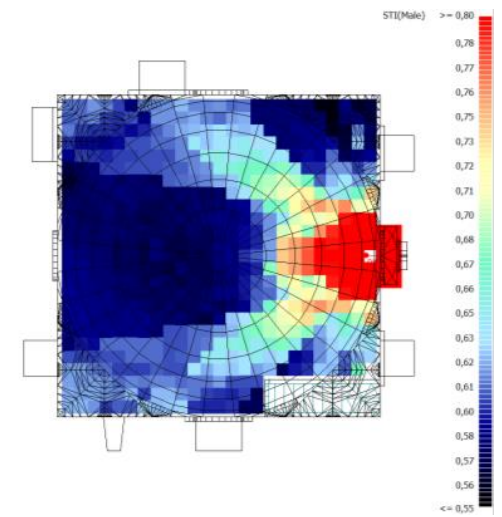

Şekil 22. Cuma namazı eylemi için STImale parametresi grid hesabl

\subsection{Taş Mescit' in akustik konfor analizi}

\subsubsection{Cuma hutbesi eylemi}

Cuma hutbesinde $375 \mathrm{~m}^{3}$ hacimli Taş Mescit için orta frekanslarda optimum çınlama süresi 1,55 sn' dir. Şekil 23' de Cuma hutbesi eylemi için simülasyon sonucunda elde edilen çınlama süreleri ve optimum kabul değerleri verilmiştir.

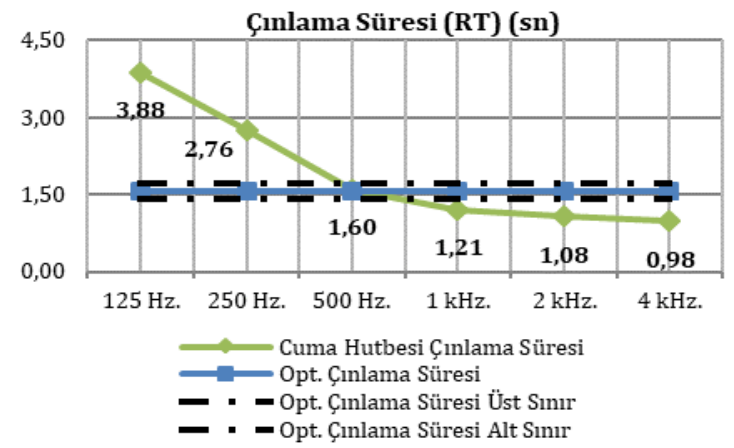

Şekil 23. Taş Mescit- Cuma namazı eylemi için elde edilen RT değerleri

Grafik incelediğinde, alçak frekanslarda kabul edilebilir değer aralığının üzerinde, orta ve yüksek frekanslarda (500 Hz. hariç) ise optimum değerin altında çınlama süresi değerleri elde edilmiştir. Alçak frekanslarda cemaatin ve havanın yutuculuğunun azalması ile yansıtıcı yüzeylerin etkisi çınlama sürelerinde artış meydana gelmiștir. Şekil 24' de Cuma hutbesi eylemi için bütün alıcı noktalarının
$1000 \mathrm{~Hz}$. frekans değerlerinden belirlenen EDT/T30 oranları verilmiștir.

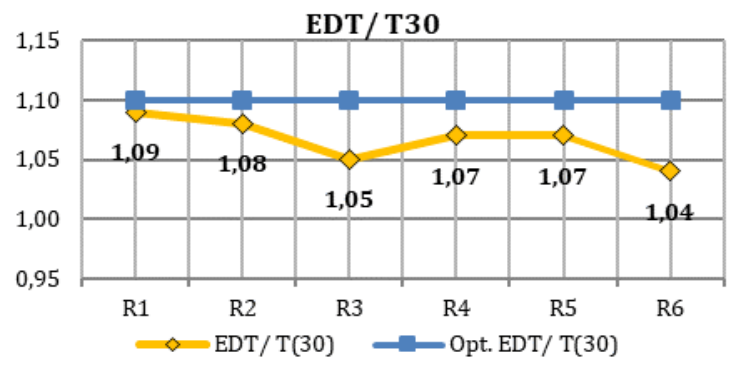

Şekil 24. Taş Mescit- Cuma hutbesi eylemi için EDT/T30 değerleri $(1000 \mathrm{~Hz}$.)

Elde edilen değerler incelendiğinde, tüm alıcı noktalarında EDT/T30 oranının birbirine yakın olduğu ve optimum değer olan 1,1'den düşük değerler elde edildiği görülmektedir. Bu duruma yapı malzemesinin oldukça yansıtıcı bir yüzey olan kesme taş olması ve mescidin küçük hacimli olması neden olmaktadır. En yüksek değer R1 alıcı noktasında elde edilirken, en düşük değer ise R6 alıcı noktasında elde edilmiştir. Simülasyonda T30 ve EDT parametrelerinin $1000 \mathrm{~Hz}$. frekansı grid hesabı Șekil 25 ' de verilmiştir.

T30 parametresi incelendiğinde, mescitte genel olarak benzer değerler görülmektedir. Mihrap çevresi, minberin ön ve yan kısımları ile arka duvara yakın kısımlarda düşük T30 değerleri elde edilmiştir. Bu duruma ses kaynağına yakın konumda olması ve yüksek enerjili erken yansımalar ulaşması neden olmuştur. Mescidin sol-arka köşesinde ve minbermihrap arasındaki bölümde direkt ses enerjisinin düşük olması nedeniyle yüksek T30 değerleri elde edilmiştir.

EDT grid hesabı incelendiğinde ise mescidin orta ve sağ arka kısımlarında, direkt sesin gelmediği minber yanında düşük değerler, mihrap bölgesinde yüksek EDT değerleri görülmüştür.

Cuma hutbesi eyleminde D50 parametresi için tüm alıcı noktalarında elde edilen değerler incelendiğinde, alçak frekanslardan yüksek frekanslara doğru gidildikçe artan yutuculuk miktarı ile çınlama
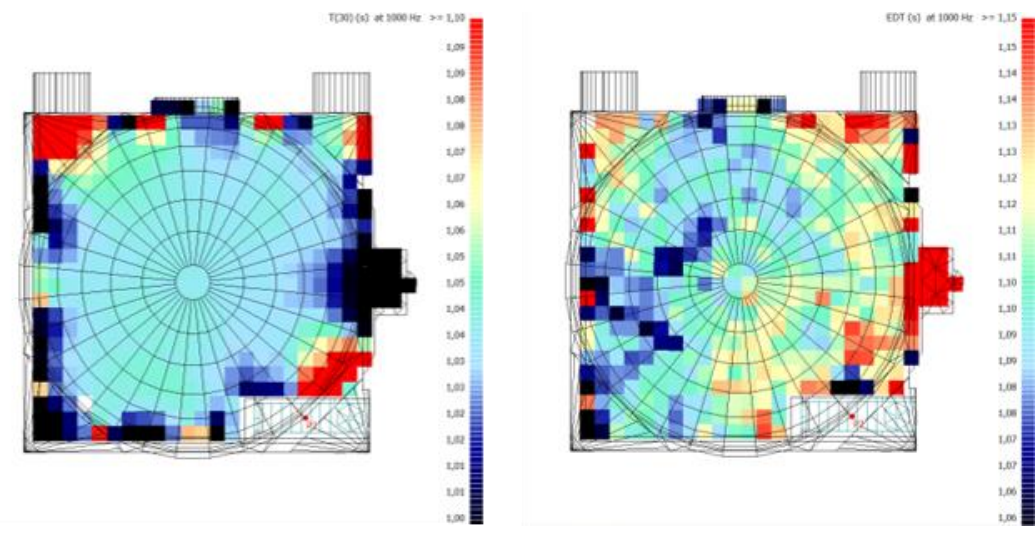

Şekil 25. Cuma hutbesi hutbesi eylemi için T30 ve EDT grid hesabı $(1000 \mathrm{~Hz}$.) 
azalarak D50 parametre değerleri artmaktadır. Alçak frekanslarda tüm alıcı noktaları optimum değer sınırı olan 0,50 değerinin altında, orta ve yüksek frekanslarda ise optimum değerin altında ve üstünde değerler elde edilmiştir. Tablo 6' da alıcı noktalarında elde edilen D50 değerleri verilmiştir.

Tablo 6. Taş Mescit- Cuma hutbesi eylemi için bütün frekanslarda elde edilen D50 değerleri

\begin{tabular}{ccccccc}
\hline \multirow{2}{*}{ D50 } & $\begin{array}{c}\mathbf{1 2 5} \\
\text { Hz. }\end{array}$ & $\begin{array}{c}\mathbf{2 5 0} \\
\text { Hz. }\end{array}$ & $\begin{array}{c}\mathbf{5 0 0} \\
\text { Hz. }\end{array}$ & $\begin{array}{c}\mathbf{1 0 0 0} \\
\text { Hz. }\end{array}$ & $\begin{array}{c}\mathbf{2 0 0 0} \\
\text { Hz. }\end{array}$ & $\begin{array}{c}\mathbf{4 0 0 0} \\
\text { Hz. }\end{array}$ \\
\hline R1 & 0,15 & 0,24 & 0,41 & 0,47 & 0,59 & 0,63 \\
R2 & 0,16 & 0,28 & 0,47 & 0,51 & 0,66 & 0,70 \\
R3 & 0,17 & 0,26 & 0,44 & 0,52 & 0,62 & 0,66 \\
R4 & 0,13 & 0,21 & 0,35 & 0,44 & 0,56 & 0,61 \\
R5 & 0,13 & 0,20 & 0,35 & 0,42 & 0,56 & 0,59 \\
R6 & 0,16 & 0,24 & 0,40 & 0,51 & 0,58 & 0,61 \\
\hline
\end{tabular}

Alıcı noktalarının 1000 Hz.' de elde edilen D50 değerleri incelendiğinde, kaynak noktasına yakın ve kısa sürede erken yansımalar alan alıcı noktalarında daha yüksek değerler elde edilmiştir. En yüksek değerler sırasıyla R3 ve R4 alıcı noktalarında, en düşük değer R5 alıcı noktasında görülmektedir.

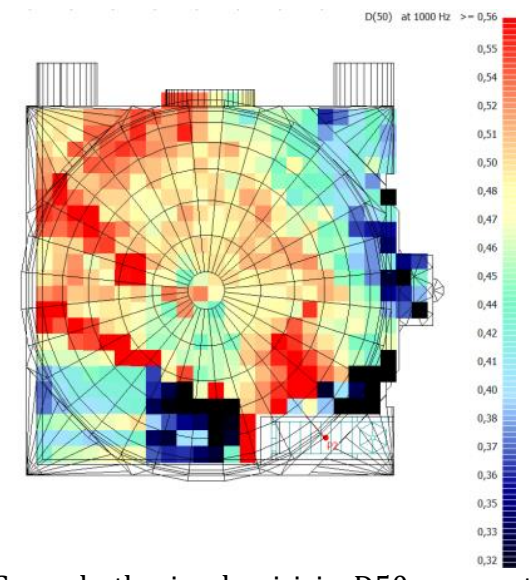

Şekil 26. Cuma hutbesi eylemi için D50 parametresi grid hesabı $(1000 \mathrm{~Hz}$.

D50 parametresinin Şekil 26' da verilen grid hesabı incelendiğinde, konuşma yönü doğrultusu ve minbere yakın bölümler ile mihrap aksına göre mescidin solarka bölümlerinde yüksek değerler; minberin akustik gölge oluşturduğu bölümlerde ve mescidin sağ-arka köșesi ile sol ön bölümlerinde düșük değerler elde edilmiştir. Sonuç olarak D50 değerlerinin yüksek olduğu kısımlarda konuşma anlaşllabilirliği yüksek, düşük olan kısımlarda ise düşük olması beklenmektedir.

C50 parametresinin alıcı noktalarında elde edilen değerleri Tablo 7'de verilmiştir. Değerler incelendiğinde, tüm alıcı noktalarında alçak frekanslarda optimum değer alt sınırı olan 0 dB' den daha düşük değerler, yüksek frekanslara doğru gidildikçe, azalan çınlama sürelerine paralel olarak yüksek C50 değerleri elde edilmiştir. Alıcı noktalarının 1000 Hz.' de elde edilen C50 değerleri incelendiğinde ise, R2 ve R3 alıcı noktalarında en yüksek, R5 alıcısında en düşük değerler görülmektedir.

Tablo 7. Taş Mescit- Cuma hutbesi eylemi için bütün frekanslarda elde edilen C50 değerleri

\begin{tabular}{ccccccc}
\hline C50 & $\mathbf{1 2 5}$ & $\mathbf{2 5 0}$ & $\mathbf{5 0 0}$ & $\mathbf{1 0 0 0}$ & $\mathbf{2 0 0 0}$ & $\mathbf{4 0 0 0}$ \\
(dB) & Hz. & Hz. & Hz. & Hz. & Hz. & Hz. \\
\hline R1 & $-7,6$ & $-5,0$ & $-1,5$ & $-0,6$ & 1,6 & 2,4 \\
R2 & $-7,1$ & $-4,2$ & $-0,5$ & 0,2 & 2,8 & 3,7 \\
R3 & $-6,8$ & $-4,5$ & $-1,1$ & 0,4 & 2,1 & 2,9 \\
R4 & $-8,4$ & $-5,8$ & $-2,6$ & $-1,1$ & 1,0 & 1,9 \\
R5 & $-8,4$ & $-6,0$ & $-2,6$ & $-1,4$ & 1,0 & 1,5 \\
R6 & $-7,3$ & $-5,0$ & $-1,8$ & 0,2 & 1,5 & 1,9 \\
\hline
\end{tabular}

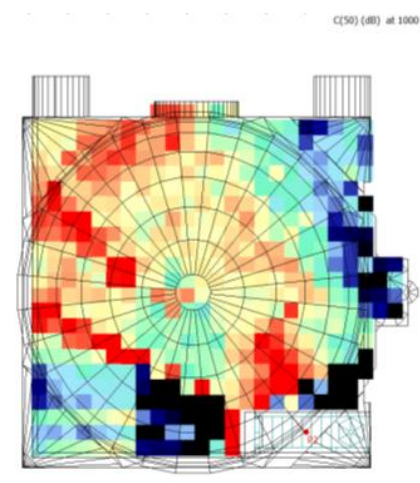

Şekil 27. Cuma hutbesi eylemi için C50 parametresi grid hesabı $(1000 \mathrm{~Hz}$.)

C50 parametresinin Şekil 27'de verilen grid hesabı incelendiğinde, D50 parametresinde olduğu gibi kaynak yönü doğrultusunun ve alıcl-kaynak arasındaki uzaklığın bu değerlerde etkili olduğu görülmüştür. Mescitte minber çevresinde akustik gölge oluşan bölümler ile gecikmiş yansımalar alan bölümlerde düșük C50 değeri elde edilmiștir. Kaynağın konuşma yönü doğrultusu ve minbere yakın bölümler ile mihrap aksına göre mescidin sağarka bölümlerinde yüksek C50 değerleri olduğu görülmektedir. Mescidin küçük ebatlı olması yan ve arka duvarlardan gelen yansımaların kısa süre içerisinde alıcı noktalarına ulaşmasını sağlayarak C50 değerlerinin yüksek elde edilmesine neden olmuştur.

Taș Mescit' in Cuma hutbesi eylemi için elde edilen STImale değerleri Şekil 28' de verilmiştir. Grafik incelendiğinde 0,55-0,60 aralığında değerler elde edildiği ve genel olarak konuşma anlașllabilirlik seviyesinin tatmin edici olduğu görülmüştür. En yüksek değer ses kaynağına yakın konumda bulunan R2 alıcı noktasında; en düşük değer ise kubbe ve duvarlardan gecikmiş yansımalar alan R5 alıcı noktasında tatmin edici seviyede elde edilmiştir.

STImale parametresinin Şekil 29'da verilen grid hesabı incelendiğinde, kaynağa yakın ve konuşma yönü doğrultusundaki minbere yakın bölgeler ile mescidin sağ-arka bölgelerinde yüksek STImale değerleri; minberin akustik gölge olușturduğu ve kubbeden gecikmiş yansımalar alan bölgelerde düşük STImale değerleri görülmüștür. 


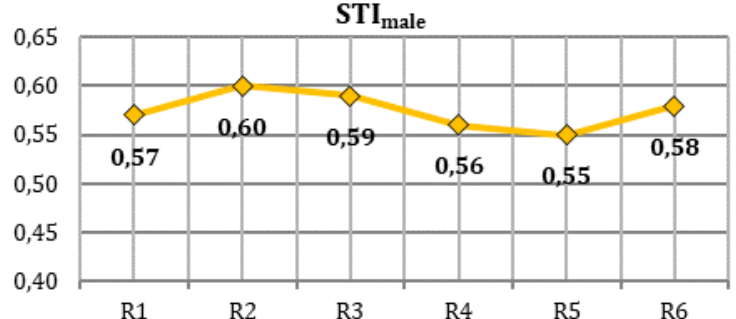

Şekil 28. Taş Mescit- Cuma hutbesi eylemi için elde edilen STImale değerleri
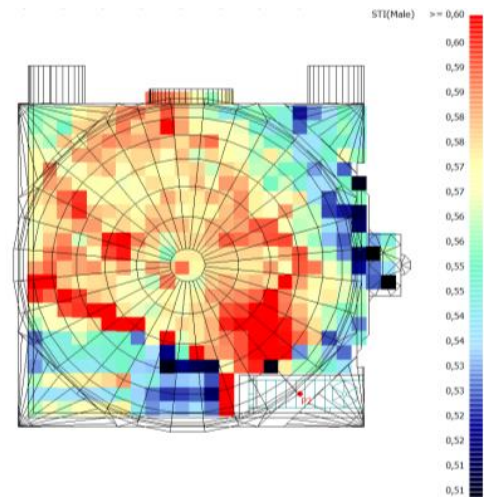

Şekil 29. Cuma hutbesi eylemi için $\mathrm{STI}_{\text {male }}$ parametresi grid hesabı $(1000 \mathrm{~Hz}$.

\subsubsection{Cuma namazı eylemi}

Taş Mescit için orta frekanslarda optimum çınlama süresi 1,55 olarak hesaplanmıştır. Şekil 30' da dini musiki amaçlı eylemlerden olan Cuma namazı eylemi için simülasyon sonucunda elde edilen çınlama süreleri ve optimum kabul değerleri verilmiştir.

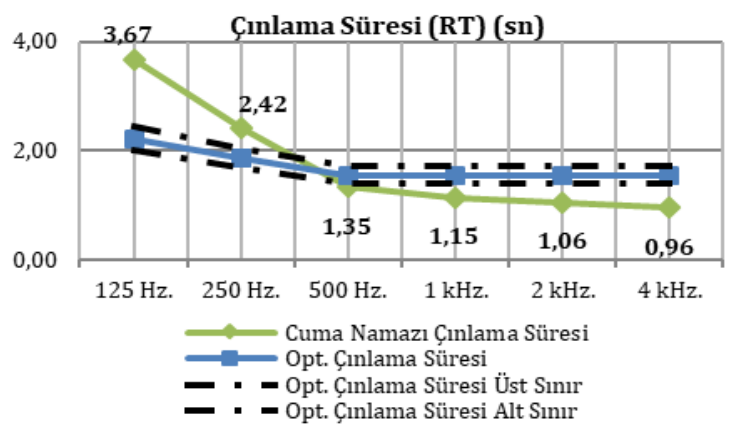

Şekil 30. Taş Mescit- Cuma namazı eylemi için elde edilen RT değerleri
Elde edilen değerler incelediğinde, alçak frekanslarda optimum değer aralığının üzerinde çınlama süresi elde edilirken, orta ve yüksek frekanslarda $(500 \mathrm{~Hz}$. hariç) ise yutuculuğun artmasıyla beraber optimum değer aralığın altında değerler elde edilmiştir. Şekil 31' de Cuma namazı eylemi için bütün alıcı noktalarında $1000 \mathrm{~Hz}$. frekans değerlerinden belirlenen EDT/T30 oranları verilmiştir.

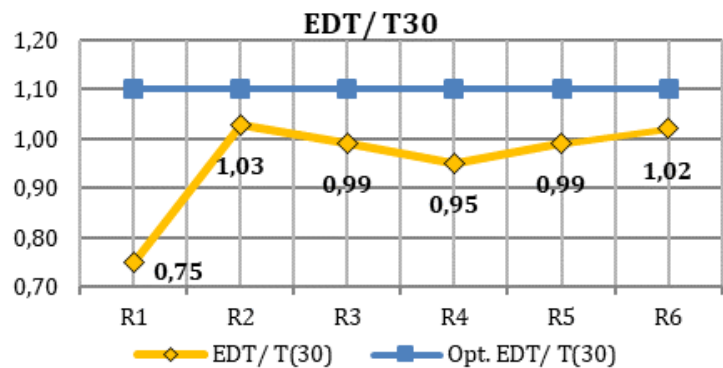

Sekil 31. Tas Mescit- Cuma namazı eylemi için EDT/T30 değerleri $(1000 \mathrm{~Hz}$.

Elde edilen değerler incelendiğinde, alıcı noktalarının genelinde EDT/T30 oranının optimum değer olan 1,1'den düșük değerler elde edildiği görülmektedir. En yüksek değer R2 alıcı noktasında, en düşük değerler ise sırasıyla R1 ve R4 alıcı noktalarında elde edilmiștir. Cuma namazı eylemi için T30 ve EDT parametrelerinin $1000 \mathrm{~Hz}$. frekansı grid hesabı Şekil 32'de verilmiștir.

T30 grid hesabı incelendiğinde, mescidin sağ ve sol yan bölümlerinde yüksek T30 değerleri, mihrap bölümünde ve sol arka köşede düşük T30 değerleri görülmektedir. Yüksek T30 değerleri o bölgelere ulaşan erken yansımaların direkt ses enerjisinden fazla olmasından; düşük T30 değerleri erken yansımaların kısa süre içerisinde ulașmasından kaynaklanmaktadır. EDT grid hesabı incelendiğinde, kaynağa yakın konumlarda ve mihrap aksında düşük değerler, kaynaktan uzaklaştıkça mihrap aksının sağ ve sol bölümlerinde yüksek değerler elde edilmiștir.

Tablo 8'de tüm alıcı noktalarında elde edilen D50 değerleri verilmiştir. 1000 Hz.' de elde edilen D50 değerleri incelendiğinde, en yüksek değerler mihrap

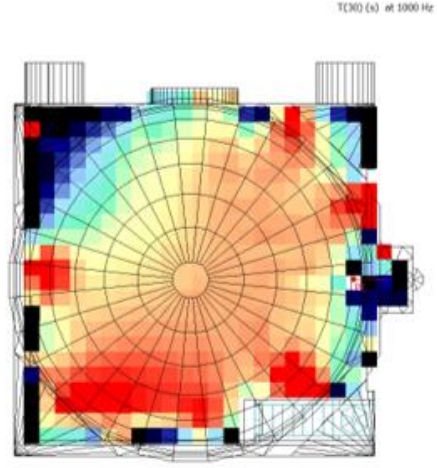

Șekil 32. Cuma namazı eylemi için T30 ve EDT grid hesabı (10
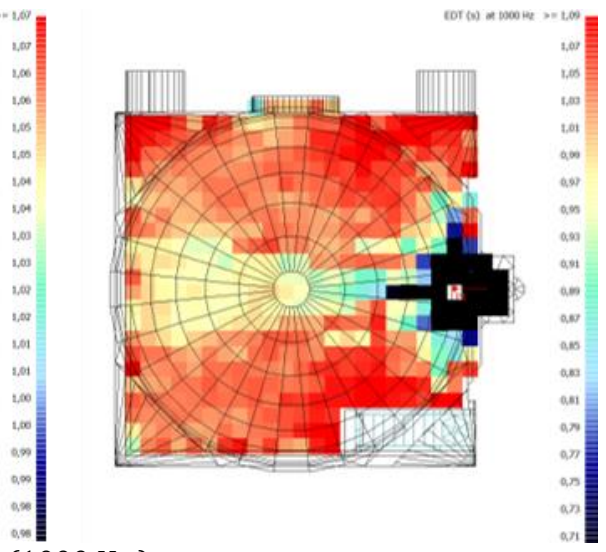
aksında bulunan alıcı noktalarında elde edilmiştir. Mihrap sayesinde gelen kısa süreli, yüksek enerjili erken yansımalar D50 değerlerinin yükselmesine neden olmuştur. Alıcı noktaları arasında en yüksek değer R1 alıcısında, en düşük değer ise R6 noktasında elde edilmiştir.

Tablo 8. Taş Mescit- Cuma namazı eylemi için bütün frekanslarda elde edilen D50 değerleri

\begin{tabular}{ccccccc}
\hline \multirow{2}{*}{ D50 } & $\begin{array}{c}\mathbf{1 2 5} \\
\text { Hz. }\end{array}$ & $\begin{array}{c}\mathbf{2 5 0} \\
\text { Hz. }\end{array}$ & $\begin{array}{c}\mathbf{5 0 0} \\
\text { Hz. }\end{array}$ & $\begin{array}{c}\mathbf{1 0 0 0} \\
\text { Hz. }\end{array}$ & $\begin{array}{c}\mathbf{2 0 0 0} \\
\text { Hz. }\end{array}$ & $\begin{array}{c}\mathbf{4 0 0 0} \\
\text { Hz. }\end{array}$ \\
\hline R1 & 0,41 & 0,54 & 0,76 & 0,83 & 0,84 & 0,86 \\
R2 & 0,21 & 0,31 & 0,48 & 0,48 & 0,58 & 0,62 \\
R3 & 0,23 & 0,34 & 0,53 & 0,53 & 0,61 & 0,65 \\
R4 & 0,19 & 0,28 & 0,48 & 0,62 & 0,64 & 0,67 \\
R5 & 0,19 & 0,28 & 0,46 & 0,47 & 0,55 & 0,59 \\
R6 & 0,18 & 0,27 & 0,45 & 0,46 & 0,54 & 0,58 \\
\hline
\end{tabular}

D50 parametresinin Şekil 33' de verilen grid hesabı incelendiğinde, mescit genelinde homojen bir dağılım görülmediği, kaynağa yakın, mihrap çevresi ve aksında yüksek değerler; ses kaynağından uzaklaştıkça, mihrap aksının sağ ve sol kısımlarında düşük değerler görülmektedir.

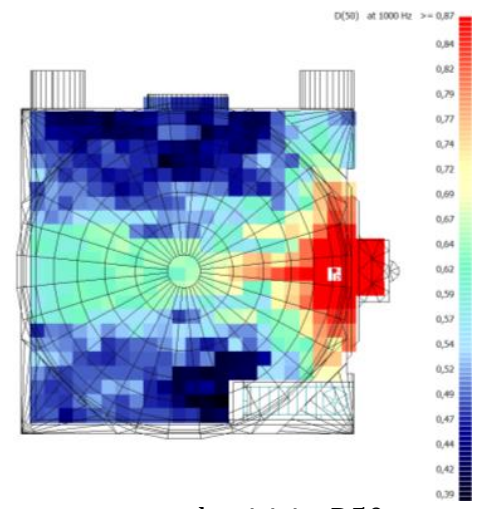

Şekil 33. Cuma namazı eylemi için D50 parametresi grid hesabi $(1000 \mathrm{~Hz}$.)

C80 parametresinin alıcı noktalarında elde edilen değerleri Tablo 9'da verilmiştir. Değerler incelendiğinde, alçak frekanslardan yüksek frekanslara doğru gidildikçe çınlama süresine ters orantılı olarak C80 değerlerinde artış görülmektedir. Alıcl noktalarının 1000 Hz.' de elde edilen C80 değerleri incelendiğinde ise, kaynağa yakın konumda bulunan R1 alıcısında en yüksek, R5 ve R6 alıcı noktalarında da en düşük değerler görülmektedir. Tüm alıcı noktalarında C80 değeri optimum değer aralığında ve konușma anlaşılabilirliği iyi elde edilmiştir.

Tablo 9. Taş Mescit- Cuma hutbesi eylemi için bütün frekanslarda elde edilen C80 değerleri

\begin{tabular}{ccccccc}
\hline C80 & $\mathbf{1 2 5}$ & $\mathbf{2 5 0}$ & $\mathbf{5 0 0}$ & $\mathbf{1 0 0 0}$ & $\mathbf{2 0 0 0}$ & $\mathbf{4 0 0 0}$ \\
(dB) & Hz. & Hz. & Hz. & Hz. & Hz. & Hz. \\
\hline R1 & $-7,6$ & $-5,0$ & $-1,5$ & $-0,6$ & 1,6 & 2,4 \\
R2 & $-7,1$ & $-4,2$ & $-0,5$ & 0,2 & 2,8 & 3,7 \\
R3 & $-6,8$ & $-4,5$ & $-1,1$ & 0,4 & 2,1 & 2,9 \\
R4 & $-8,4$ & $-5,8$ & $-2,6$ & $-1,1$ & 1,0 & 1,9 \\
R5 & $-8,4$ & $-6,0$ & $-2,6$ & $-1,4$ & 1,0 & 1,5 \\
R6 & $-7,3$ & $-5,0$ & $-1,8$ & 0,2 & 1,5 & 1,9 \\
\hline
\end{tabular}

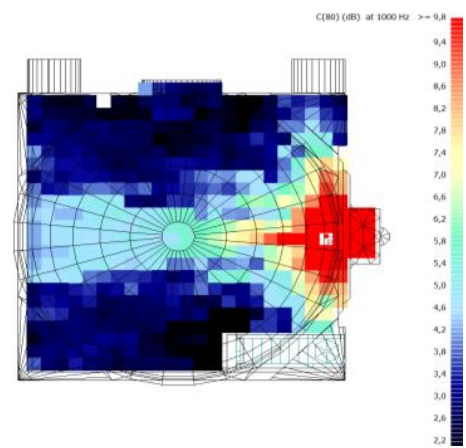

Şekil 34. Cuma namazı eylemi için C80 parametresi grid hesabi $(1000 \mathrm{~Hz}$.

C80 parametresinin Şekil 34' de verilen grid hesabı incelendiğinde, kaynağa yakın, mihrap çevresi ve aksında yüksek değerler; ses kaynağından uzaklaştıkça, mihrap aksının sağ ve sol kısımlarında düșük değerler elde edilmiștir. Mescitte genel olarak mihrap aksı dışındaki bölgelerde optimum değer aralığında C80 sonuçları görülmüștür. $\mathrm{Bu}$ durum mescidin bu eylemler için uygun olduğunu ve açlktan Kur'an-1 Kerim okunurken seslerin birbirini maskelemeden, ahenk içerisinde işitileceğini göstermektedir.

Taș Mescit' in Cuma namazı eylemi için elde edilen STImale değerleri Şekil 35' de verilmiștir.

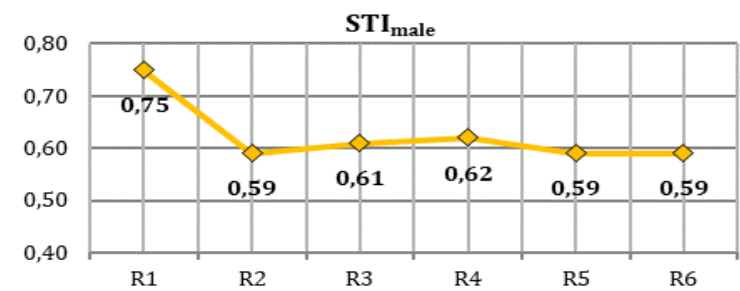

Şekil 35. Taş Mescit- Cuma namazı eylemi için elde edilen STImale değerleri

Grafik incelendiğinde, 0,59-0,75 aralığında değerler elde edildiği ve genel olarak konuşma anlaşılabilirlik seviyesinin iyi olduğu görülmüștür. En yüksek değer kaynak noktasına yakın olması ve mihrap ile minberden yüksek enerjili erken yansımalar alması nedeniyle R1 alıcı noktasında mükemmel seviyede

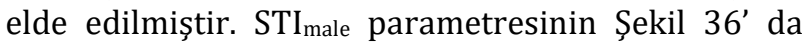
verilen grid hesabı incelendiğinde, D50 parametresi gibi kaynak noktasına yakın bölgelerde yüksek değerler, kaynaktan uzaklaştıkça düşük değerler elde edilmiştir.

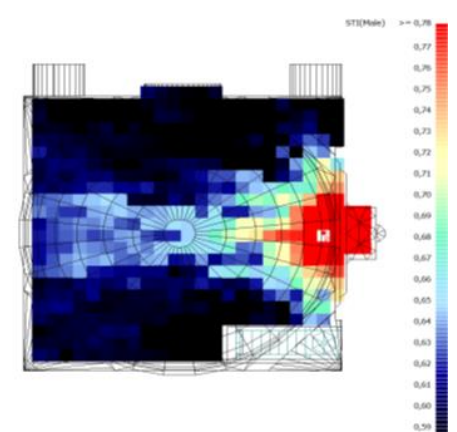

Şekil 36. Cuma namazı eylemi için $S T I_{\text {male }}$ parametresi grid hesabi $(1000 \mathrm{~Hz}$. 


\section{Tartışma ve Sonuç}

$\mathrm{Bu}$ çalışma kapsamında Konya mahalle mescitlerinden; plan şeması, hacim, yapı malzemesi ve kubbeye geçiş elemanları bağlamında birbirinden farklı olan hem konuşma hem de dini musiki işlevini taşıyan Hoca Hasan Mescidi ve Taş Mescit' in akustik konfor analizi yapılmıştır. Örneklem mescitlerin akustik performanslarl, Sketch Up programiyla 3 boyutlu modellemesi yapılarak Odeon Akustik Simülasyon Programı aracılığıyla hacim akustiği parametreleri (RT, EDT, D50, C50, C80 ve STI) hesaplanmıştır. Parametrelerin değerlendirilmesinde literatürden elde edilen optimum değerler kullanılmıştır.

Simülasyon sonucunda Hoca Hasan Mescidi ve Taş Mescit için elde edilen değerlerdeki farklılıkların temel nedeni yapı malzemelerinin birbirinden farklı olmasından kaynaklanmaktadır. Kubbe, kaynak noktası ve alıcı noktaları arasındaki ilişki de farklı sonuçlarda etkili olmaktadır. Ayrıca seçilen mahalle mescitlerinde özel olarak yer alan kubbeye geçiş elemanlarından tromplar, içbükey yüzeyinden dolayı geç süreli erken yansımaların gelmesinde rol oynamıştır.

Bütün eylemlerde Hoca Hasan Mescidi' nin çınlama süreleri Taş Mescit' e göre daha düşük değerler almıştır. Hoca Hasan Mescidi daha büyük hacimli olmasına rağmen, bu durum Taş Mescit' in yutuculuk özelliği az, yansıtıcı yüzey olan kesme taştan, Hoca Hasan Mescidi' nin ise daha yutucu özelliğe sahip tuğla üzeri sıva malzemeden yapılmasından kaynaklanmaktadır. Mescitlerde genel olarak kişi başına düşen hacmin yüksek olması nedeniyle alçak frekanslarda yüksek çınlama süreleri elde edilmiştir. $\mathrm{Bu}$ yüzden orta ve yüksek frekanstaki sesler, alçak frekanstaki sesler tarafindan daha fazla maskelenecektir.

Hoca Hasan Mescidi' nin Cuma namazı eyleminde mihrap ile minber arasındaki bölgenin minberden gelen erken yansımalar sayesinde, Taş Mescit' in Cuma namazı eyleminde ise merkezdeki aksın, mihraptan gelen erken yansımalar nedeniyle yüksek değerler elde edilmesi; kaynağa yakın konumda bulunan yansıtıcı yüzeyin konuşma anlaşılabilirliği üzerindeki önemli etkisini göstermektedir.

Mihrabın etkisi özellikle Cuma namazı eyleminde görülmektedir. Taş Mescit' in Cuma namazı eylemindeki çınlama süreleri Hoca Hasan Mescidi' ne göre daha yüksektir. Bu durum kaynağın konuşma yönünün mihraba dönük olmasından ve Taş Mescit' in mihrabının kesme taş, Hoca Hasan Mescidi' nin alçı olmasından kaynaklanmaktadır. Mescitlerde minber yan duvara bitişik olduğu için parametre değerlerinde daha homojen bir dağılım gerçekleşmiş ve iki mescit için de minber çevresindeki alanda benzer sonuçlar görülmüştür.
Konuşma anlaşılabilirliği ve netlik parametreleri açısından Hoca Hasan Mescidi'nde Taş Mescit' e göre daha yüksek değerler elde edilmiştir. Değerlendirilen iki eylem için kaynağa yakın konumda bulunan ve kısa süre içinde güçlü erken yansımalar alan bölgelerde yüksek değerler; kaynaktan daha düşük enerjili direkt ses ve gecikmiş yansımalar alan bölgelerde düşük değerler görülmektedir. Anlaşlabilirlik düzeyi ise Hoca Hasan Mescidi'nde daha yüksek olmakla beraber iki mescitte de iyi seviye elde edilmiştir.

Hoca Hasan Mescidi ve Taş Mescit' in küçük ebatlı olması, arka duvardan ve kubbeden gelen rahatsız edici ekoların oluşmasını engellemiştir. Mescitlerde incelenen eylemlerde rahatsızlık verici ekoların ve odaklanma sorunlarının olmadığı tespit edilmiştir. Sonuç olarak, her iki mescit için elde edilen parametre değerleri incelendiğinde Hoca Hasan Mescidi'nin Taş Mescit' e göre daha iyi akustik konfor şartlarına sahip olduğu görülmektedir.

$\mathrm{Bu}$ çalışma tarihi mahalle mescitlerinin işitsel kültürel miras olarak akustik koşullarının belgelenmesini desteklemek ve devamlılığını sağlamak amacıyla yapılmıştır. Mescitlerde restorasyon çalıșması yapılırken, görsel olduğu kadar akustik koşulları olumsuz etkileyecek müdahalelerin engellenmesi, özgün durumuna benzer malzemelerle yenileme çalışmaları yapılması sağlanmalıdır.

Tarihi mahalle mescitlerinde genel olarak kişi başına düşen hacim miktarının fazla olması ve yansıtıcı yüzeylerden oluşması nedeniyle alçak frekans çınlama süreleri yüksek çıkmaktadır. Bunun sonucunda sesler birbirini maskeleyerek anlaşılabilirlik azalmaktadır. Bu nedenle mescitlerin içerisinde yansıtıcı-yutucu yüzey dengesi sağlanmalıdır. Mescitlerde farklı doluluk oranlarında benzer akustik koşullar sağlamak için, zemin kaplamasının yutuculuk değerlerinin, cemaatin yutuculuk değerine yakın olmasına dikkat edilmelidir. Mihrap-minber formu ve bulundukları konum akustik performans üzerinde etkili olmaktadır. Namaz eyleminde, mescidin mihrap yüzeylerinin saçıcı olması daha homojen bir dağılım ortaya çıkaracaktır. Minber ise kaynağa yakın konumda bulunmasından dolayı yansıtıcı yüzeylerden oluşmalı, formunda akustik gölge oluşturacak tasarımlardan kaçınılmalıdır. Mahalle mescitlerinin küçük hacimli olması ve ses sistemi kullanılmadan konuşma anlaşılabilirliğinin iyi seviyede olması nedeniyle akustik konforu olumsuz etkilememek için ses sistemi kullanmaktan kaçınılmalıdır. Yeni mescit tasarımlarında kubbe ve içbükey yüzeyler tercih edilecekse; içbükey yüzeyin merkez noktası, kaynak ve alıcı noktası arasındaki ilișki incelenmeli, odaklama sorununun oluşması engellenmelidir. 


\section{Teşekkür}

$\mathrm{Bu}$ çalışma "Anadolu Selçuklu Dönemi Mahalle Mescitlerinin Akustik Konfor Analizi: Konya Örneği" başlıklı yüksek lisans tezinden üretilmiştir.

\section{Etik Beyanı}

Bu çalışmada, "Yükseköğretim Kurumları Bilimsel Araştırma ve Yayın Etiği Yönergesi" kapsamında uyulması gerekli tüm kurallara uyulduğunu, bahsi geçen yönergenin "Bilimsel Araștırma ve Yayın Etiğine Aykırı Eylemler" başlı̆̆ı altında belirtilen eylemlerden hiçbirinin gerçekleștirilmediğini taahhüt ederiz.

\section{Kaynakça}

[1] Grabar, 0. 1983. Symbols and Signs in Islamic Architecture, Architecture and Community: Building in the Islamic World Today, (ed. Renata Holod), Millerton, NY, 25-32.

[2] Abdou, A. A. 2003. Measurement of acoustical characteristics of mosque in Saudi Arabia. The Journal of the Acoustical Society of America, 113(3), 1505-1517.

[3] Kayll, M. 2005. Acoustic Solutions in Classic Ottoman Architecture, FSTC Limited, Manchester.

[4] Orfali, W. 2007. Room Acoustic and Modern Electro-Acoustic Sound System Design During Constructing and Reconstructing Mosques, Technischen Universitat Berlin, Ph.D. Thesis, Berlin.

[5] Sü Gül, Z., Çalışkan, M., Tavukçuoğlu, A. 2014. Geçmişten Günümüze Süleymaniye Camii Akustiği, Megaron. Yıldız Teknik Üniversitesi, Mimarlık Fakültesi E-Dergi, 9(3), 201-216.

[6] Kaygısız, A., 2019. Mimar Sinan Camilerinden Şemsi Ahmet Paşa Camii (Üsküdar) ile T.C. Diyanet İşleri Başkanlığı Tip 3 Camii'nin Akustik Açıdan Karşılaştırılması. İstanbul Teknik Üniversitesi, Fen Bilimleri Enstitüsü, Yüksek Lisans Tezi, 133-136, İstanbul.

[7] Selçuklu Belediyesi, 2017. Hoca Hasan Mescidi. http://www.selcuklumirasi.com/architecturedetail/hoca-hasan-mescidi (Erişim Tarihi: 18.05.2020).
[8] Cantay, T. 1982. XII.-XIII. Yüzyıllarda Anadolu'da Cephe Mimarisinin Gelişmesi. İstanbul Üniversitesi, Sosyal Bilimler Enstitüsü, Yayımlanmamış Doktora Tezi, İstanbul.

[9] Turan, Ş. 2018. Türk Mimarisinde Kullanılan Kubbeye Geçiş Elemanları; 13.YY. Anadolu Selçuklu Dönemi Konya Mahalle Mescitleri Örneği. Necmettin Erbakan Üniversitesi, Fen Bilimleri Enstitüsü, Yüksek Lisans Tezi, 65-82, Konya.

[10] Baş, T. 2008. Anadolu Selçuklu Dönemi Konya Mahalle Mescitlerinin Restorasyon Sorunları. Selçuk Üniversitesi, Fen Bilimleri Enstitüsü, Yüksek Lisans Tezi, 8-50, Konya.

[11] Konyalı, İ. H. 2007. Abideleri ve Kitabeleriyle Konya Tarihi, 129,144s, Konya.

[12] Vakıflar Genel Müdürlüğü, Hoca Hasan MescidiTaş Mescit/Rölöve, Restitüsyon ve Restorasyon Projeleri.

[13] Tuna, R. 2020. Rumeysa Tuna Fotoğraf Arşivi.

[14] Selçuklu Belediyesi, 2017. Hacı Ferruh Mescidi. http://www.selcuklumirasi.com/architecturedetail/haci-ferruh-mescidi, (Erişim Tarihi: 18.05.2020).

[15] Ateş, E. G. 2007. Kültürel Mirasımız Olan Yerebatan Sarnıcının Akustik Sorunlarının İncelenmesi, İstanbul Teknik Üniversitesi, Fen Bilimleri Enstitüsü, Yüksek Lisans Tezi, 49s. İstanbul.

[16] Elkhateeb, A., Adas, A., Attia, M., Balila, Y. 2015. The Acoustics Of Masjids, Why They Differ From The Classical Speech Rooms, The 22nd International Congress on Sound and Vibration, 12-16 Temmuz 2015, Florence, İtalya, 5s.

[17] Mehta, M., Johnson, J., Rocafort, J. 1999. Architectural Acoustic: Princibles and Design, Prentice-Hall, New Jersey, USA.

[18] Barron, M. 2009. Auditorium Acoustics and Architectural Design, Second Edition, Spon Press, London and New York.

[19] Long, M. 2006. Architectural Acoustics, Elsevier Academic Press, California, USA, 598-673s.

[20] ODEON A/S., 2016. ODEON Room Acoustics Software Version 14 Manual. 